\title{
Snow and Ice Volume on Mount Spurr Volcano, Alaska,
}

\section{1}

By Rod S. March, Lawrence R. Mayo, and Dennis C. Trabant

U.S. GEOLOGICAL SURVEY

Water-Resources Investigations Report 97-4142

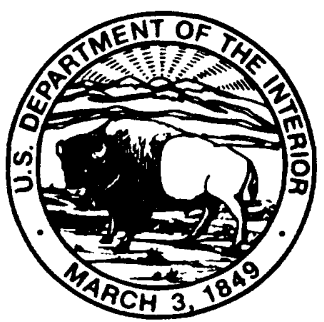

Fairbanks, Alaska 


\section{U.S. DEPARTMENT OF THE INTERIOR}

BRUCE BABBITT, Secretary

U.S. GEOLOGICAL SURVEY

GORDON P. EATON, Director

For additional information write to:

District Chief

U.S. Geological Survey

4230 University Drive, Suite 201

Anchorage, AK 99508-4664

http://www-water-ak.usgs.gov
Copies of this report can be purchased from:

U.S. Geological Survey

Branch of Information Services

Box 25286

Denver, CO 80225-0286 


\section{CONTENTS}

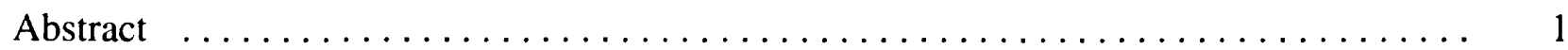

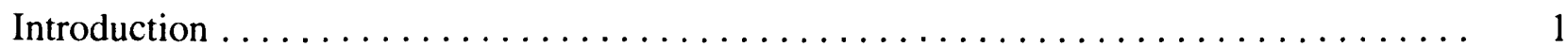

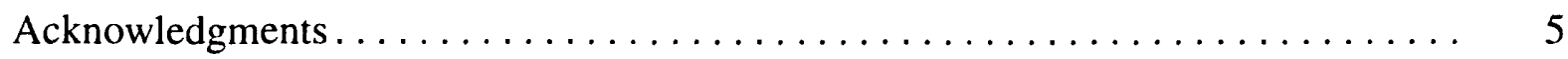

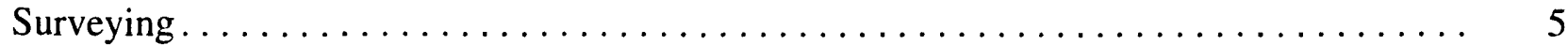

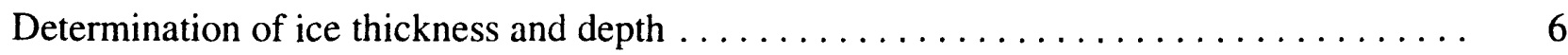

Measurements ........................................ 6

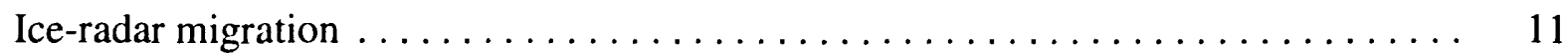

Contouring ice thickness and bed topography...................... 12

Seasonal snow ....................................... 18

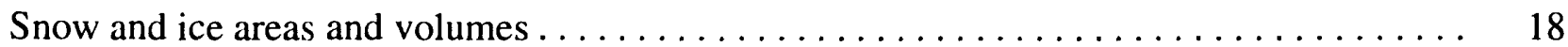

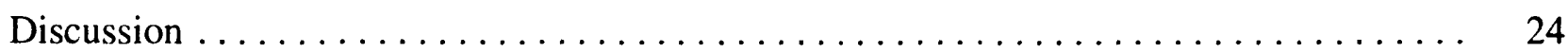

Selected subglacial features............................... 24

Use of glacier volumes at Mount Spurr to improve volume-estimation methods. . . . . 28

Glaciovolcanic hazards and comparison with other volcanoes............ 29

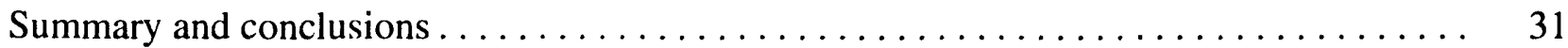

References cited....................................... 32

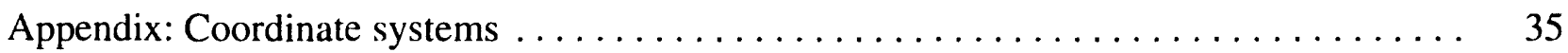

\section{PLATES}

[Plates in pocket]

1. Altitude of base and surface of glaciers on Mount Spurr, Alaska

2. Ice thickness and surface contours of glaciers on Mount Spurr, Alaska

\section{FIGURES}

1. Map showing location of Mount Spurr, Alaska .................. 2

2. Photograph of Mount Spurr Volcano viewed from the south-southwest ........ 4

3. Diagram showing the exact ellipsoidal solution and the more commonly used approximate spherical solution for the location of all possible

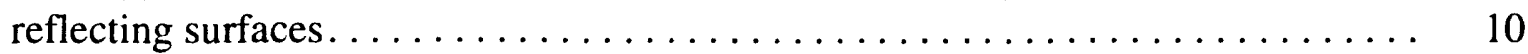

4. Photograph of Mount Spurr Volcano seen from the southwest showing

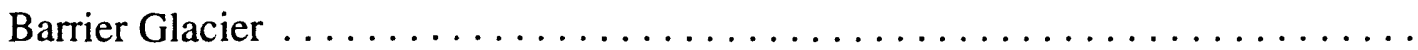

5. Photograph of Mount Spurr Volcano seen from the southeast showing

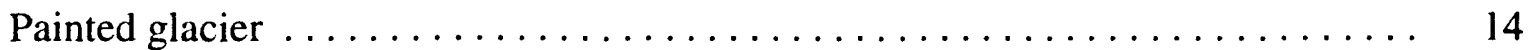

6. Scatter plot of measured ice thickness versus glacier surface slope. ......... 15

7. Scatter plot of basal shear stress versus glacier surface slope or sine of

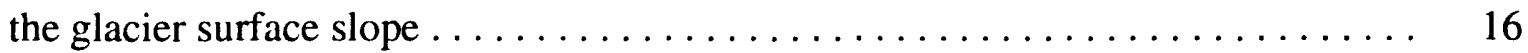

8. Map showing horizontal surface ice velocities derived from ogive spacings .... 17

9. Longitudinal profiles of Barrier Glacier's surface and bed ............. 24 
10. Photograph of Mount Spurr Volcano seen from the east with Capps

Glacier in the foreground $\ldots \ldots \ldots \ldots \ldots \ldots \ldots \ldots \ldots \ldots \ldots \ldots \ldots \ldots \ldots \ldots \ldots \ldots, 26$

11. Contour map of glacier surface and bed topography of the summit region

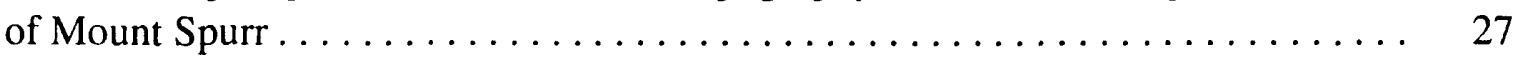

12. Longitudinal profiles of upper South branch of Capps Glacier's surface and bed $\ldots \ldots \ldots \ldots \ldots \ldots \ldots \ldots \ldots \ldots \ldots \ldots \ldots \ldots \ldots \ldots \ldots \ldots \ldots \ldots \ldots \ldots \ldots \ldots, 28$

13. Log-log scatter plot of glacier volume versus glacier area for Mount Spurr glaciers and Cascade Range glaciers on volcanoes $\ldots \ldots \ldots \ldots \ldots \ldots$

\section{TABLES}

1. Coordinates of survey control stations in the Mount Spurr area $\ldots \ldots \ldots \ldots \ldots 6$

2. Ice-thickness measurements ........................... 7

3. Seasonal snow data from U.S. Soil Conservation Service sites near Mount Spurr .................................. 18

4-11. Areas and volumes of snow and ice in:

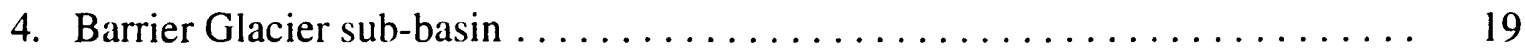

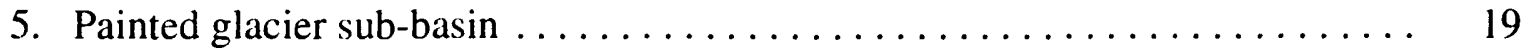

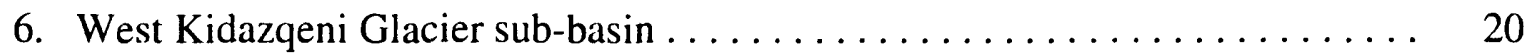

7. East Kidazqeni Glacier sub-basin....................... 20

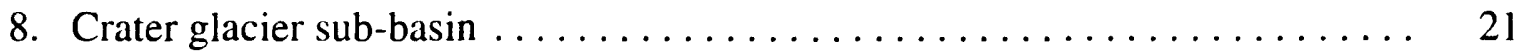

9. South branch, Capps Glacier sub-basin ................... 21

10. Main branch, Capps Glacier sub-basin..................... 22

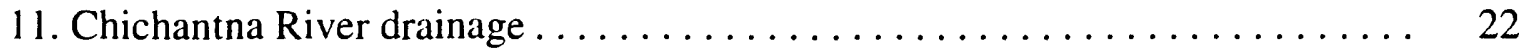

12. Summary of areas and volumes of snow and ice on Mount Spurr and their seasonal minimums and maximums.................... 23

13. Summary of snow and ice minimum seasonal area (September), maximum seasonal area (May), and volume above altitude of glacier termini ............ 


\begin{tabular}{rll}
\hline Multiply & by & To obtain \\
\hline meter $(\mathrm{m})$ & 3.281 & foot \\
kilometer $(\mathrm{km})$ & 0.6214 & mile \\
square kilometer $\left(\mathrm{km}^{2}\right)$ & 0.3861 & square mile \\
cubic kilometer $\left(\mathrm{km}^{3}\right)$ & 0.2399 & cubic mile \\
cubic meter per second $\left(\mathrm{m}^{3} / \mathrm{s}\right)$ & 35.31 & cubic foot per second \\
kilopascal $(\mathrm{kPa})$ & 0.1450 & pound per square inch \\
$\mathrm{grad}$ & 0.9 & degree \\
degree Celsius $\left({ }^{\circ} \mathrm{C}\right)$ & 1.8. then add 32 & degree Fahrenheit \\
& &
\end{tabular}

\section{VERTICAL DATUM}

Altitudes are measured relative to the National Geodetic Vertical Datum of 1929 (NGVD of 1929) which is defined as follows: A geodetic datum derived from a general adjustment of the first-order level nets of both the United States and Canada, formerly called "Mean Sea Level." The year indicates the time of the last general adjustment.

\section{HORIZONTAL DATUM}

The horizontal datum for all locations in this report is the North American Datum of 1927 (NAD of 1927).

\section{SYMBOLS AND ABBREVIATIONS}

$A$

glacier surface area, in square kilometers

deg degree

E

UTM Easting

F

shape factor

$h$

glacier thickness, measured perpendicular to glacier bed, in meters

$h$

glacier thickness, measured vertically between glacier surface and glacier bed, in meters

$k$

scale factor

$k$

mean scale factor

$\mathrm{m} / \mu \mathrm{s}$

meter per microsecond

$\mathrm{MHz} \quad$ megahertz

$\min \quad$ minutes

$r^{2} \quad$ coefficient of determination

$S \quad$ transmitter-receiver separation, in meters 


$\begin{array}{ll}t_{d} & \text { time delay, in microseconds } \\ \text { UTM } & \text { Universal Transverse Mercator } \\ \hat{V} & \text { estimated glacier volume, in cubic kilometers } \\ v_{a} & \text { velocity of light in air, in meters per microsecond } \\ v_{i} & \text { velocity of light in ice, in meters per microsecond } \\ X_{v} & \text { local sea-level coordinate, increasing eastward } \\ Y_{o} & \text { local sea-level coordinate, increasing northward } \\ Z & \text { altitude above sea level, in meters } \\ \alpha & \text { glacier surface slope } \\ \beta & \text { average glacier bed slope } \\ \beta_{R} & \text { bed slope at the basal reflection point } \\ \mu & \text { micro } \\ \tau_{b} & \text { yield stress of ice, in kilopascals } \\ \tau_{b} & \text { basal shear stress, in kilopascals }\end{array}$




\title{
Snow and Ice Volume on Mount Spurr Volcano, Alaska, 1981
}

\author{
By Rod S. March, Lawrence R. Mayo and Dennis C. Trabant
}

\section{Abstract}

Mount Spurr (3,374 meters altitude) is an active volcano 130 kilometers west of Anchorage, Alaska, with an extensive covering of seasonal and perennial snow, and glaciers. Knowledge of the volume and distribution of snow and ice on a volcano aids in assessing hydrologic hazards such as floods, mudflows, and debris flows.

In July 1981, ice thickness was measured at 68 locations on the five main glaciers of Mount Spurr: 64 of these measurements were made using a portable 1.7 megahertz monopulse ice-radar system, and 4 measurements were made using the helicopter altimeter where the glacier bed was exposed by ice avalanching. The distribution of snow and ice derived from these measurements is depicted on contour maps and in tables compiled by altitude and by drainage basins.

Basal shear stresses at 20 percent of the measured locations ranged from 200 to 350 kilopascals, which is significantly higher than the 50 to 150 kilopascals commonly referred to in the literature as the "normal" range for glaciers. Basal shear stresses higher than "normal" have also been found on steep glaciers on volcanoes in the Cascade Range in the western United States.

The area of perennial snow and ice coverage on Mount Spurr was 360 square kilometers in 1981 , with an average thickness of $190 \pm 50$ meters. Seasonal snow increases the volume about 1 percent and increases the area about 30 percent with a maximum in May or June. Runoff from Mount Spurr feeds the Chakachatna River and the Chichantna River (a tributary of the Beluga River). The Chakachatna River drainage contains 14 cubic kilometers of snow and ice and the Chichantna River drainage contains 53 cubic kilometers.

The snow and ice volume on the mountain was $67 \pm 17$ cubic kilometers, approximately 350 times more snow and ice than was on Mount St. Helens before its May 18, 1980, eruption, and 15 times more snow and ice than on Mount Rainier, the most glacierized of the measured volcanoes in the Cascade Range. On the basis of these relative quantities, hazard-producing glaciovolcanic phenomena at Mount Spurr could be significantly greater than similar phenomena at Cascade Volcanoes.

\section{INTRODUCTION}

Following the eruption of Mount St. Helens in May 1980, the U.S. Geological Survey accelerated the assessment of hazards at other volcanoes. On the basis of their historical eruptive patterns, Mount Spurr (fig. 1) and several other volcanoes in Alaska, including Mount Redoubt, were identified as being among those volcanoes in the U.S. with the greatest potential for eruption in the next 50 years (Les Laird, U.S. Geological Survey, written commun., 1980). 

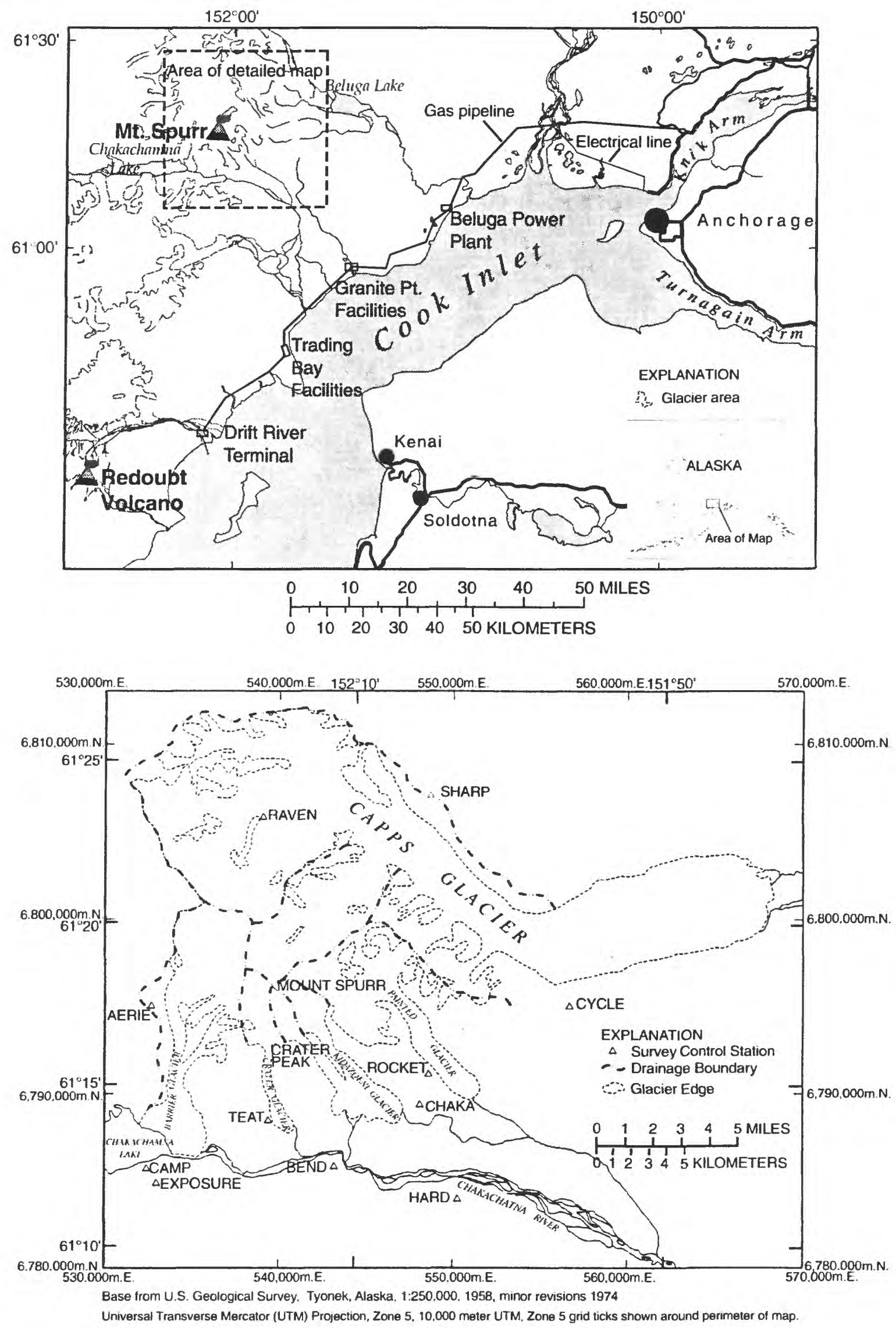

Figure 1. Location of Mount Spurr, Alaska. Detailed map shows glaciers and other features of Mount Spurr. 
Study of the 1980 eruption of Mount St. Helens has increased awareness of the significance of snow and ice to hydrologic hazards such as floods and lahars that result from volcanic eruptions. It is now recognized that knowledge of the quantity and distribution of snow and ice on a volcano is a component of volcano-hazard analysis. Major and Newhall (1989) have reviewed historical eruptions in which the perturbation of snow and ice has resulted in floods and lahars. Their summary includes descriptions of both the physical processes and the losses of lives and property that occurred during these events.

Mount Spurr Volcano is in an undeveloped area $130 \mathrm{~km}$ west of Anchorage, $100 \mathrm{~km}$ northwest of Kenai, and 40-70 km from oil and gas facilities in and along Cook Inlet (fig. I). Chakachamna Lake (fig. 1), southwest of Mount Spurr, is partly dammed by Barrier Glacier, which flows from Mount Spurr. The lake has been considered for a hydropower site (Bechtel Civil \& Minerals Inc., 1983; Jackson, 1961; Johnson, 1950). The Beluga coal field lies 40-50 km to the east of Mount Spurr (Schmitt, 1984).

Mount Spurr is the most northeastern active volcano of the Aleutian arc. The volcano has two vents which grew after the avalanche collapse of ancestral Mount Spurr in the late Wisconsinan or early Holocene. The collapse of ancestral Mount Spurr was a Bezymianny-type (sector collapse) eruption (Siebert, 1984) that left a 5- by 7.5-km horseshoe-shaped caldera and produced a volcanic debris avalanche of a few cubic kilometers that traveled at least $25 \mathrm{~km}$ to the east (Nye and Turner, 1990). The rim of the caldera is visible in the cover photo. The older of the two active vents is in the center of the caldera and now forms the summit of Mount Spurr at 3,374 m altitude. It is currently a small, partly ice-filled crater that has not erupted in historic times, but continues to steam intermittently and shows evidence of snow melt in photographs (Wescott and others, 1988). The youngest tephra deposit recognized from this vent is dated at 5,200 radiocarbon years before present (Riehle, 1985). The other active vent, Crater Peak (cover photo and fig. 2), grew in the south breach in the caldera at about 2,200 m altitude and erupted in July 1953 (Juhle and Coulter, 1955 ) and in June, August, and September 1992 (Keith, 1995). Before the 1953 eruption, the Crater Peak crater was partly filled by a small glacier that flowed from a breach in the south rim of the crater. The 1953 eruption removed much of this small glacier and caused major flooding and geomorphic changes along the Chakachatna River. During the 1992 eruption, hot pyroclastic debris interacted with the snowpack to form mixed snow-pyroclast flows (Waitt, 1995; Meyer and Trabant, 1995). Some of the pyroclastic flows were large enough to melt glacier ice and generate volcanic mudflows or lahars that reached the Chakachatna River. Pyroclastic flows from the 1992 eruption eroded small segments of the steep, heavily crevassed parts of Kidazqeni Glacier but did not significantly alter the glacier regime. However, variable amounts of volcanic ash deposited on the surface of Kidazqeni Glacier may have some effect on the rate of ice ablation.

During both the 1953 and 1992 eruptions, large debris dams were built across the Chakachatna River where tributary streams heading on Crater Peak entered the river. Lahars generated on the flanks of the volcano formed thick fans of boulders and gravel at these confluence sites (fig. 2; Meyer and Trabant, 1995). Although the debris dams have been mostly removed by erosion, during periods of low flow on the Chakachatna River, zones of slack water, some as long as $8 \mathrm{~km}$, develop upstream from these remnant dams. 


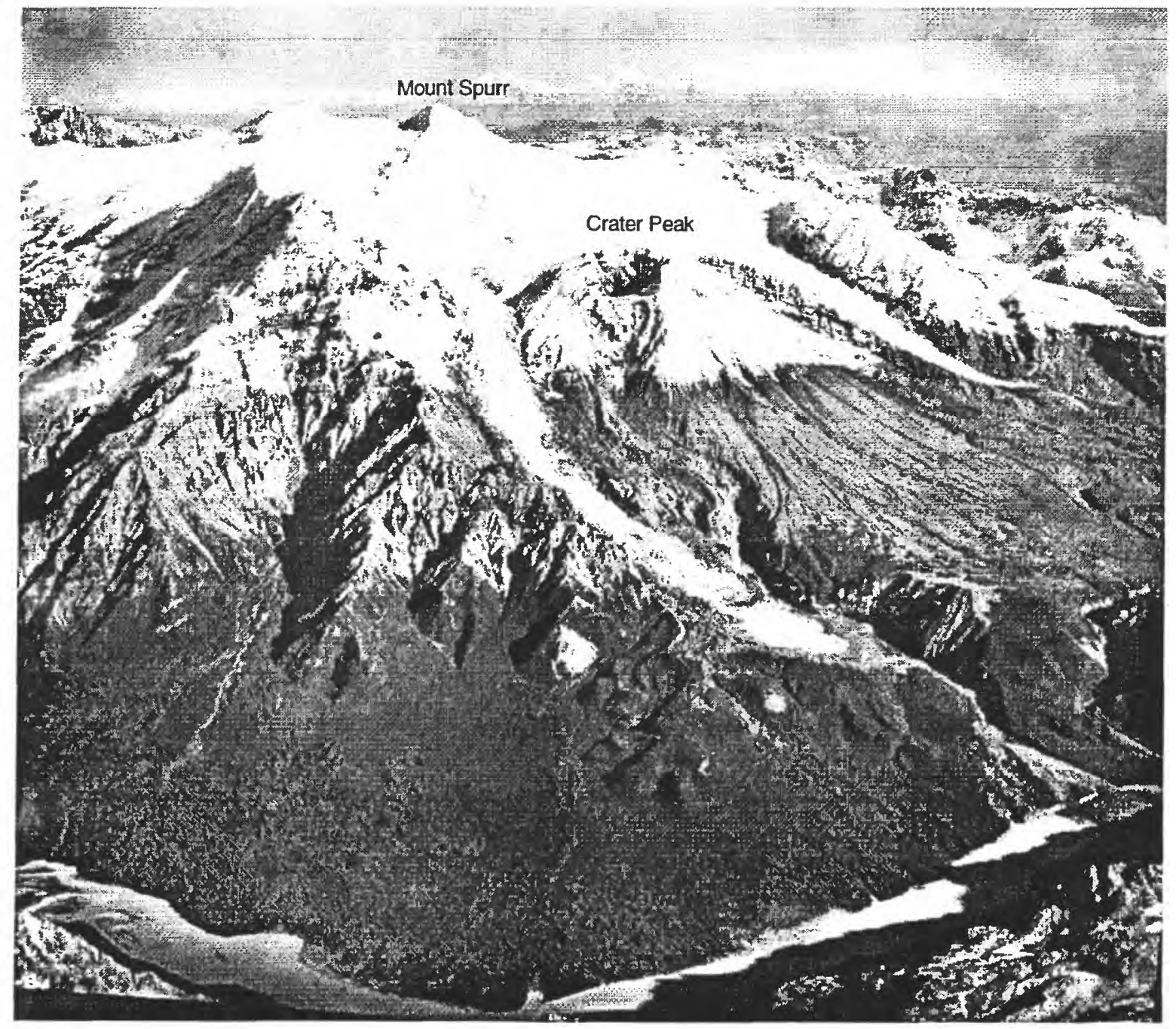

Figure 2. Mount Spurr Volcano viewed from the south-southwest on September 4, 1966, after a fresh snowfall above 1,200 meters altitude. Chakachatna River flows east (left to right) across the bottom of the photo. Most of this reach of the river is a narrow lake that was dammed by debris flow deposits from the 1953 and 1992 eruptions (Juhle and Coulter, 1955; Keith, 1995). Part of the debris dam can be seen at the right edge of the photo. Crater glacier (informal name) is in the middle of the photo flowing past the west side of Crater Peak, the source of the 1953 and 1992 eruptions. (U.S. Geological Survey photograph by Austin Post, \#666-8.)

During field work in 1981, water vapor was observed emitting from a glacier crevasse at about $2,600 \mathrm{~m}$ altitude on the south flank of the summit cone, roughly midway between the summit and Crater Peak. Zones of fumarolic activity on the flanks of the Mount Spurr summit cone have been reported by Wescott and others (1988). 
Given the apparent large quantities of snow and ice on Mount Spurr, and its recent eruptive history, the USGS began work to determine the ice volume and distribution. Field work for the project was done in July 1981. The extension of geodetic control to new stations around Mount Spurr to permit the surveying of measurement sites has been reported by March, Mayo, and Trabant (1986). This report reviews the geodetic control and describes measurements of ice thickness, the derivation of ice thickness and bed topography maps, and the compilation of areas and volumes of snow and ice by altitude zones and drainage basins.

\section{Acknowledgments}

The authors would like to acknowledge Dr. Melinda Brugman for her invaluable assistance and enthusiasm during the field survey of the volcano. Helicopter pilots, Mike Chase and George Nisson, skillfully and safely placed field parties on highly crevassed and steep glacier surfaces, which was necessary to obtain the ice-thickness measurements.

\section{SURVEYING}

Three second-order control stations established in 1953 by the National Geodetic Survey (NGS) served as the basis for our surveys. Minor vertical adjustments (based on surveys by the U.S. Geological Survey in 1978 and in this study) were made to these stations to account for the tectonic lowering in the area during the Alaska earthquake of 1964. Seven new, monumented survey stations and one temporary survey station (table 1) were installed near Mount Spurr in July 1981. These stations provide a reference so that measurement sites on Mount Spurr for this and any future studies could be located precisely in the Universal Transverse Mercator (UTM) system, which is the basis for U.S. Geological Survey topographic maps (March, Mayo, and Trabant, 1986).

A local coordinate system, based on the Universal Transverse Mercator (UTM) grid and similar to that used by the authors elsewhere (Mayo and others, 1979; Trabant and Mayo, 1979), was adopted. Unlike UTM, the local coordinate system uses the sea-level surface for horizontal scale, thus simplifying and enabling computations in the field with hand calculators. See the appendix for details.

At 61 of the 64 sites where measurements of ice thickness were made using ice radar, the transmitter and receiver locations were surveyed from control stations by the foresight technique (angle, distance). Atmospheric refraction was calculated from vertical angles to nearby monumented survey stations measured at the time of ice-radar surveys and used to estimate an atmospheric refraction correction between the survey instrument and ice-radar measurement sites. For further information about the calculation of foresight surveys and atmospheric refraction, see Mayo and others (1979). The estimated standard error in horizontal position of these sites is about $\pm 1.5 \mathrm{~m}$. This is largely determined by the uncertainty of the microwave distance meter used, because it is not a distance standard and therefore depends on field calibration for its accuracy. For locations on the upper Capps Glacier surveyed from station Sharp or station Raven, the error is $\pm 3.0 \mathrm{~m}$ due to additional uncertainty with the location of those stations (March, Mayo, and Trabant, 1986). The estimated standard error in vertical position is less than $\pm 0.5 \mathrm{~m}$. 
Table 1. Coordinates of survey control stations in the Mount Spurr area. NGS second-order control stations are listed in all capitals. Horizontal datum is NAD of 1927; vertical datum is NGVD of 1929 (from March, Mayo, and Trabant, 1986)

\begin{tabular}{|c|c|c|c|c|c|}
\hline \multirow{2}{*}{$\begin{array}{l}\text { Survey control } \\
\text { station } \\
\text { (fig. 1) }\end{array}$} & \multicolumn{2}{|c|}{ UTM Zone 5} & \multicolumn{2}{|c|}{ Local sea level } & \multirow{2}{*}{$\frac{\text { Altitude }}{\mathrm{Z}}$} \\
\hline & $\begin{array}{l}\text { Easting } \\
\text { (meters) }\end{array}$ & $\begin{array}{l}\text { Northing } \\
\text { (meters) }\end{array}$ & $\begin{array}{c}\mathrm{X}_{o} \\
\text { (meters) }\end{array}$ & $\begin{array}{c}\mathrm{Y}_{o} \\
\text { (meters) }\end{array}$ & \\
\hline BEND & 543187.11 & 6785741.69 & 23196.09 & 15747.78 & 874.78 \\
\hline CHAKA & 548070.73 & 6789323.67 & 28081.53 & 19331.11 & 978.17 \\
\hline TEAT & 539402.97 & 6788402.09 & 19410.51 & 18409.24 & 719.33 \\
\hline Camp & 532407.24 & 6785637.01 & 12412.10 & 15643.13 & 735.72 \\
\hline Exposure & 532968.60 & 6784815.30 & 12973.67 & 14821.09 & 1368.29 \\
\hline Aerie & 532647.57 & 6795081.86 & 12652.52 & 25091.67 & 2184.36 \\
\hline Rocket & 548596.90 & 6791106.78 & 28607.90 & 21114.90 & 963.09 \\
\hline Cycle & 556666.99 & 6795042.66 & 36680.94 & 25052.19 & 940.42 \\
\hline Sharp & 548769.20 & 6807121.30 & 28780.26 & 37135.57 & 1430.21 \\
\hline Raven & 539086.30 & 6805851.14 & 19093.72 & 35865.08 & 1776.23 \\
\hline Hard & 550281.47 & 6783896.39 & 30293.09 & 13901.72 & 820.30 \\
\hline
\end{tabular}

The remaining seven ice measurement locations could not be surveyed, so were determined by correlating observations of the local terrain with a 1:50,000 scale topographic map (an enlarged composite of 1:63,360 scale U.S. Geological Survey topographic maps). The error in these positions varies greatly depending on the local terrain and may be as large as $500 \mathrm{~m}$.

Ice-radar transmitter and receiver locations were averaged to give a single "midpoint" location for each measurement site and are reported in local sea-level scale coordinates. See appendix on coordinate systems for a description of the conversion to UTM coordinates.

\section{DETERMINATION OF ICE THICKNESS AND DEPTH}

\section{Measurements}

Measurements of ice thickness were made at 68 sites on the glaciers using two methods: surface ice radar and direct observation of the glacier bed at near-vertical ice cliffs (table 2).

At four locations, near-vertical ice cliffs were found where glaciers were exposed to their beds. The vertical ice thickness was measured by flying a helicopter to the ice cliff and recording the helicopter altimeter reading at the bottom and the top of the cliff. The uncertainty in these measurements is estimated to be \pm 15 percent.

At 64 locations, the ice thickness perpendicular to the glacier bed was measured using a portable ground-based $1.7 \mathrm{MHz}$ monopulse ice-radar system, similar to that described by Watts and Wright (1981) and by Driedger and Kennard (1984, 1986a,b). The system uses an oscilloscope as 


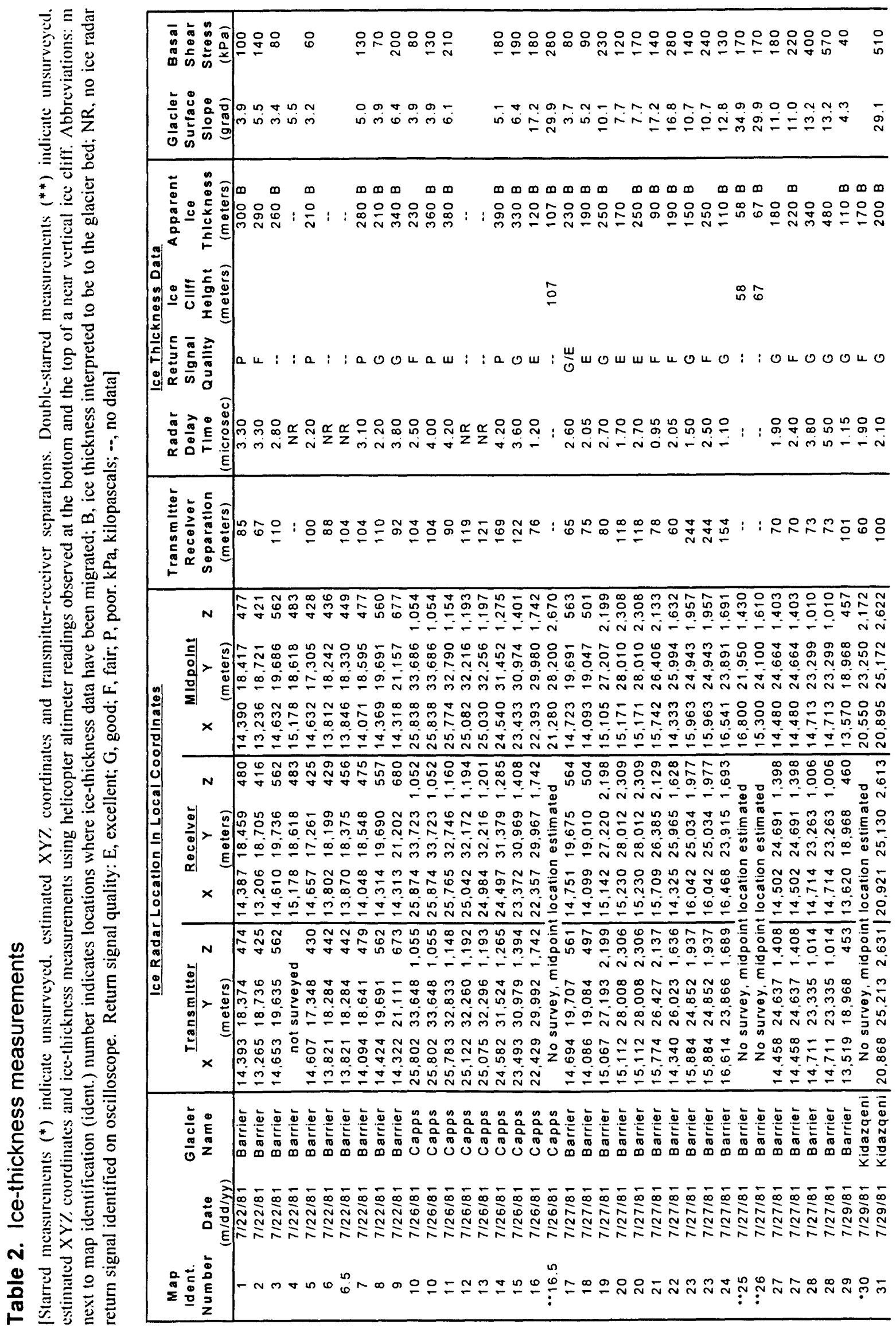




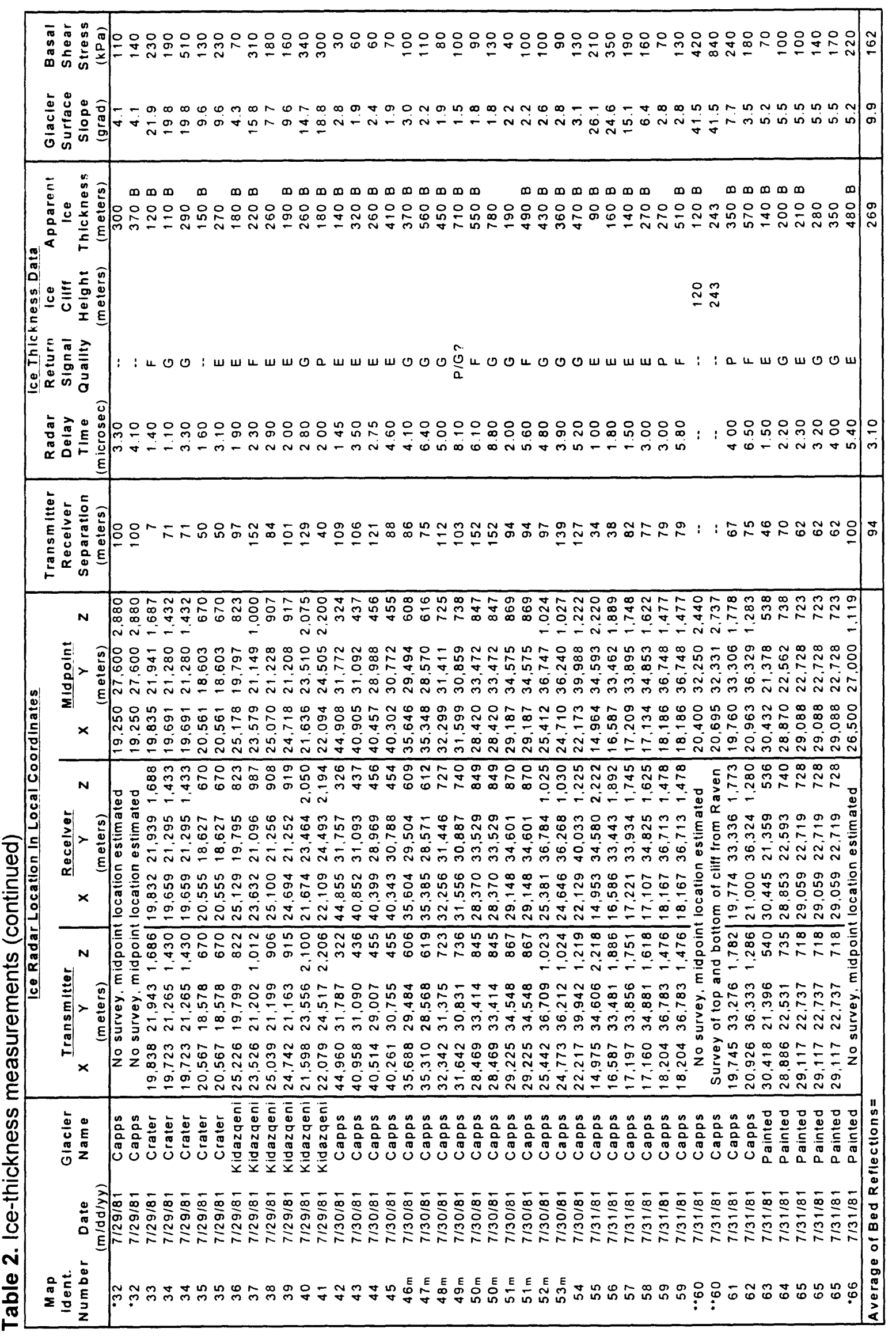


the receiver to measure the time between the arrival of the transmitted radio wave that travels through the air and the radio wave that travels through the ice, reflecting off the glacier bed interface. The distance between the monopulse transmitter and the oscilloscope receiver was typically about $100 \mathrm{~m}$ at Mount Spurr (see table 2 for site-specific separations).

The standard method used for estimating ice thickness perpendicular to the subglacial bed from a measured time delay is explained by Mayo and Trabant (1982) and by Driedger and Kennard $(1984,1986 \mathrm{a})$. The ice thickness, $h$ (in meters), perpendicular to the glacier bed is:

$$
h=\frac{1}{2} \sqrt{v_{i}^{2}\left(t_{d}+\frac{S}{v_{a}}\right)^{2}-S^{2}}
$$

where $v_{a}$ and $v_{i}$ are the speeds of light in air and ice respectively (in meters per microsecond, $\mathrm{m} / \mu \mathrm{s}$ ), $S$ is the transmitter-receiver separation distance (in meters), and $t_{d}$ is the time delay (in microseconds).

For the constants in this equation, the values $v_{a}=299.7 \mathrm{~m} / \mu \mathrm{s}$ and $v_{i}=168 \mathrm{~m} / \mu \mathrm{s}$ are assumed (Watts and England, 1976; Mayo and Trabant, 1982). A speed of $168 \mathrm{~m} / \mu$ s is equivalent to an index of refraction of 1.784 for ice. Extrapolation from optical data presented in a review by Warren (1984) suggests that the index of refraction for $0^{\circ} \mathrm{C}$ ice at $1.7 \mathrm{MHz}$ is between 1.788 and 1.790 . No direct measurements have been made at this frequency and temperature. Error in the index of refraction probably results in less than 1 percent error in ice thickness.

The data obtained at each field site and the ice-thickness values calculated from equation 1 are listed in table 2.

The exact solution for the location of all possible reflecting surfaces defines an ellipsoid with the transmitter and receiver as foci (Jacobel and Raymond, 1984). Equation 1 is an approximate solution that defines a sphere lying tangent to the inside of the ellipsoidal solution with center midway between the transmitter and receiver (fig. 3). This approximation is exact if the distances from the transmitter and receiver to the basal reflection point are the same. This will most often be true for valley glaciers if the transmitter and receiver are separated laterally across the glacier for radar measurements in the middle of the glacier, and separated up and down the glacier for radar measurements near the margin of the glacier. For other cases, the approximation underestimates the thickness by a small amount that increases with the ratio of $S$ to $h$. See Kennard (1983, Appendix C) for further discussion of the approximation.

Errors may arise from several sources. The analysis assumes that the first signal recorded on the oscilloscope is an air wave. This may not be true if the glacier surface is sufficiently convex (bulging) between the transmitter and the receiver. Under these conditions, the air wave may not reach the receiver and the first signal received by the oscilloscope may have traveled through the glacier or along the surface of the glacier at a slower velocity than an air wave. Hence, the calculated ice thickness, which assumes that the first arrival is an air wave, would underestimate the ice thickness by an amount that depends on the relative values of $h$ and $S$ and whether or not the nearsurface glacier material is snow or ice. The larger the ratio of $S$ to $h$, the greater the underestimation. In the worst case for the Spurr data, the underestimation could reach about 30 percent, but on average would be only about 5 percent. This is an uncertain source of error and the specific conditions under which this occurs, if in fact it occurs at all, are unknown. 


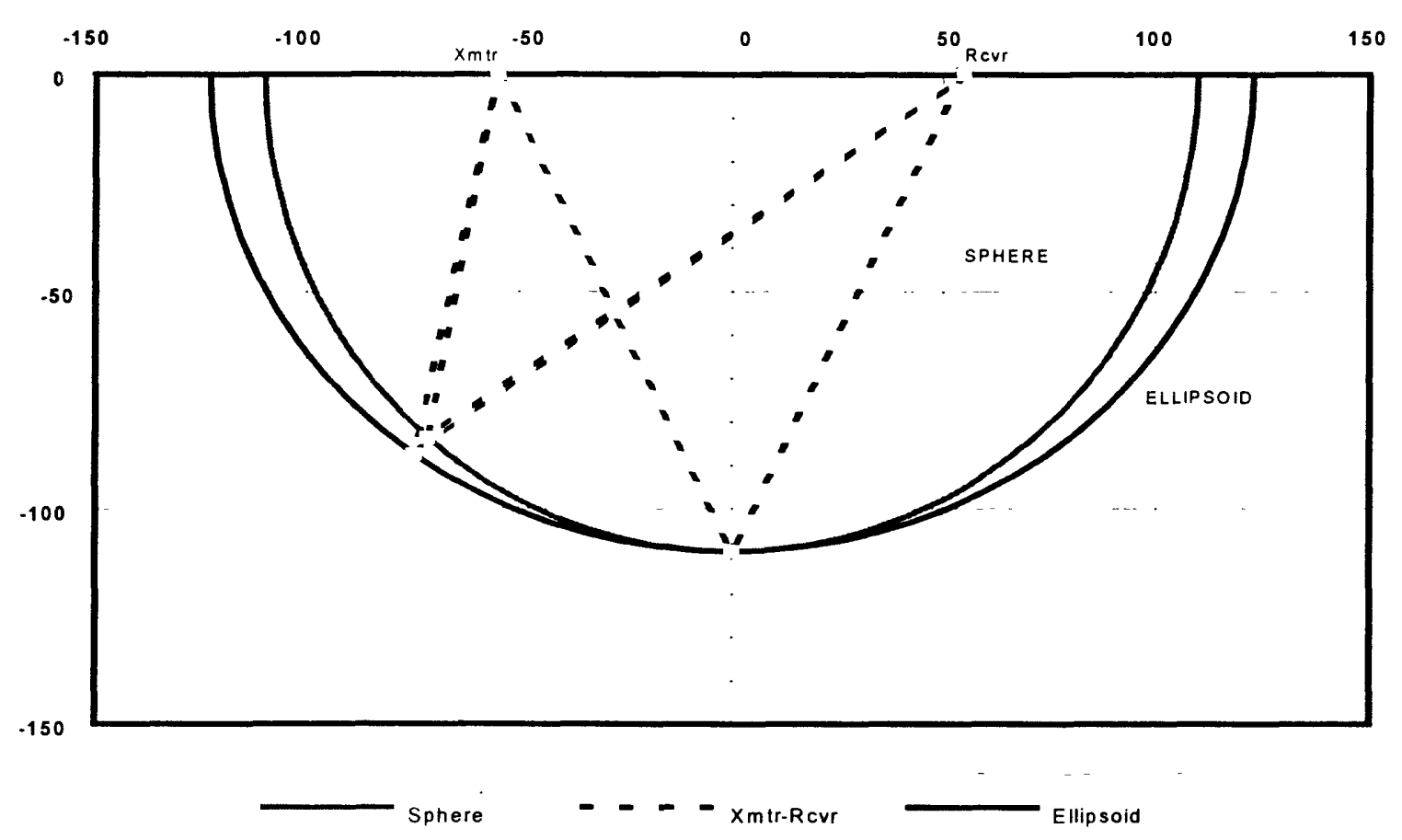

Figure 3. The exact ellipsoidal solution and the more commonly used approximate spherical solution for the location of all possible reflecting surfaces. Dashed lines show hypothetical ice radar paths to bed. (Xmtr stands for transmitter and Rcvr for receiver.)

Errors in the time delay measurement arise from two sources. The oscilloscope sweep rate standard error is \pm 4 percent and the estimated standard error in reading the time delay from the scope is \pm 4 percent for the poorer quality returns and \pm 2 percent for the better quality returns. Combined, these yield an estimated standard error for the ice thickness perpendicular to the glacier bed of less than \pm 6 percent.

Additional errors may result when the source of a particular reflection identified on the oscilloscope trace cannot be identified unambiguously as the glacier bed. The reflector could be a rock wall above the glacier surface or an englacial layer of volcanic ash, buried avalanche debris, or basal debris carried into the glacier along a thrust plane. Unless there was evidence to indicate otherwise, it was assumed that the reflector (or the deepest reflector in the case of multiple reflectors) was the bed. Other evidence typically examined includes nearby radar measurements, glacier flux continuity, and stereo vertical photography (see section on contouring techniques for further explanation). This information was sufficient to justify rejection of two poor quality single reflection returns ( 3 percent of the radar data) and five of the deepest of multiple reflection returns ( 8 percent of the radar data); all other radar data were accepted. 
Overall, of 64 radar measurements, about 70 percent were usable single reflections, 11 percent were multiple reflections in which the deepest reflector was chosen as the bed, 8 percent were multiple reflections in which a reflector shallower than the deepest was chosen as the bed, 3 percent were single reflections that were rejected, and 8 percent yielded no identifiable reflections.

\section{Ice-Radar Migration}

Ice radar determines the ice thickness perpendicular to the glacier bed at the closest bed point to the radar instrumentation. Depending on the magnitude of the slope of the bed, an iterative calculation, referred to as "migration," may be necessary to convert the ice thickness to a vertical ice depth (vertical ice depth is necessary for integrating with map areas to get ice volumes) (Driedger and Kennard, 1984, 1986a). If the bed slope, $\beta$, is uniform between the reflection point and the basal point below the transmitter-receiver midpoint, the following calculation is made:

$$
h^{\prime}=\frac{h}{\cos \beta}
$$

where $h$ is the ice thickness perpendicular to the bed and $h^{\prime}$ is the vertical ice depth at the ice radar midpoint. If the bed is not uniform, we must estimate the bed slope at the basal reflection point, $\beta_{R}$ and the glacier bed slope, $\beta$, which is now the average bed slope between the basal reflection point and the basal point that lies directly below the transmitter-receiver midpoint. In this case the following calculation is used to arrive at the migrated ice depth, $h^{\prime}$ :

$$
h^{\prime}=h \cos \left(\beta_{R}\right)+h \sin \left(\beta_{R}\right) \tan \beta
$$

If the bed flattens from the reflection point to the midpoint as is common in valley glaciers where much of the radar migration is across the glacier towards the valley walls, migration using equation 2 will lead to overestimation of the ice depth and errors that may be just as large as if the radar data were not migrated. The bed slopes, $\beta$ and $\beta_{R}$, are arrived at by an iterative process. First, a thickness contour map is made of the unmigrated data and subtracted from the glacier surface contour map to give a first draft map of bed topography. Bed slopes near each measurement site are estimated from this bed map and used to recalculate ice depth, $h^{\prime}$, using equation 2 or 3 . The migrated radar data are then used to make a second generation thickness contour map and the process is repeated. After a few iterations, the contours generally cease changing (Driedger and Kennard, 1986a). The closer the spacing of the ice-radar measurements, the better the definition of the topographic variability of the bed surface and the greater the accuracy. Where the radar measurements are widely spaced, variations in the bed surface near radar measurement sites are sometimes inferred from glacier surface topography and crevasse patterns as identified on stereo vertical photography.

Generally, the ice-radar measurements at Mount Spurr were not migrated because the change in ice volumes from migration would have been small compared to the cumulative error from other sources. Migration on slopes less than $10 \mathrm{grad}$, about the average at the Mount Spurr measurement sites, would change the ice thickness by less than 1 percent. Sites numbered $46-53$ in the central reach of Capps Glacier were migrated because of the steepness of the bed slopes and because these 
sites occur in pairs on transects and could be migrated laterally across the glacier toward the valley walls very quickly without the more lengthy iterative migration steps outlined above.

\section{Contouring Ice Thickness and Bed Topography}

Extensive estimation of ice depth was necessary to draw bed contours in areas where little or no ice-radar data were available, particularly high up on the mountain where poor weather hampered field efforts. The estimation method used was guided by simple physical principles and photographic observations, because of various problems with application of the empirically based and theoretically based methods at Mount Spurr. Contouring of measured and estimated ice thickness and glacier bed altitude was done by hand as the low spatial density of measurements was considered inadequate for application of computer based contouring algorithms.

Two empirical relations developed to estimate the ice volumes on unmeasured Cascade volcanoes (Kennard, 1983; Driedger and Kennard, 1984, 1986a) were considered. They relate the glacier area and surface slope to the ice volume on the basis of eight measured glaciers on Cascade volcanoes. Driedger and Kennard (1986b) also applied them with some success to nine similarsized glaciers in Sweden, British Columbia, California, Montana, and Wyoming.

Despite these promising applications of Kennard's empirical relations elsewhere, it was considered inappropriate to apply the technique to the volume estimation of the glaciers on Mount Spurr because the relations were derived from glaciers significantly smaller than those on Mount Spurr and its use would have required extrapolation as much as an order of magnitude beyond the limits of the original data from which the relations were derived. There is the additional problem that volumes resulting from application of Kennard's relation are sensitive to how the glacier boundaries are chosen, a difficult task at Mount Spurr where the top third of the mountain is a nearly continuous ice field $100-300 \mathrm{~m}$ thick without clearly defined glacier or ice-stream boundaries (see cover photo, fig. 4, and fig. 5).

Theoretically based estimation techniques were also considered for estimating the ice thicknesses at points as they may be more universally applicable than Kennard's method which attempts to estimate the entire volume of the glacier at once. These estimation techniques, shown in figure 6, included the following: (1) application of plasticity theory to glacier flow with yield stresses ranging from 100-150 kPa (Nye, 1951, p. 554; Paterson, 1981, p. 86); (2) linear regression between the glacier thickness $(h)$ and the inverse of the sine of the surface slope $(\alpha)$, variables which are linearly related in theory; and (3) the non-linear power fit (regression between $\log (h)$ and $\log [1 / \sin \alpha]$ ), which can be thought of as still using the linear relation between the glacier thickness and the inverse of the sine of the surface slope, but adding a non-linear component due to variance in the basal shear stress (that is, no longer treat the basal shear stress as a constant; the basal shear stress at radar measurement sites is not well approximated by a constant in the range $50-150 \mathrm{kPa}$, nor is it linearly related to the surface slope, fig. 7). None of these techniques produced a coefficient of determination $\left(\mathrm{r}^{2}\right)$ better than 0.6 .

About one-fifth of the basal shear stress values (table 2 and fig. 7) were significantly greater than $200 \mathrm{kPa}$ and several values were more than $300 \mathrm{kPa}$, whereas $50-150 \mathrm{kPa}$ is considered to be the "normal" range for glaciers (Paterson, 1981, p. 40, 86). The highest basal shear stresses are somewhat suspicious and may be in error due to error in the assumed shape factor or incorrect topographic contours from which the surface slopes were measured. However, in general the high stresses appear to be normal for steep glaciers on volcanoes. Basal shear stresses at 30 percent of 


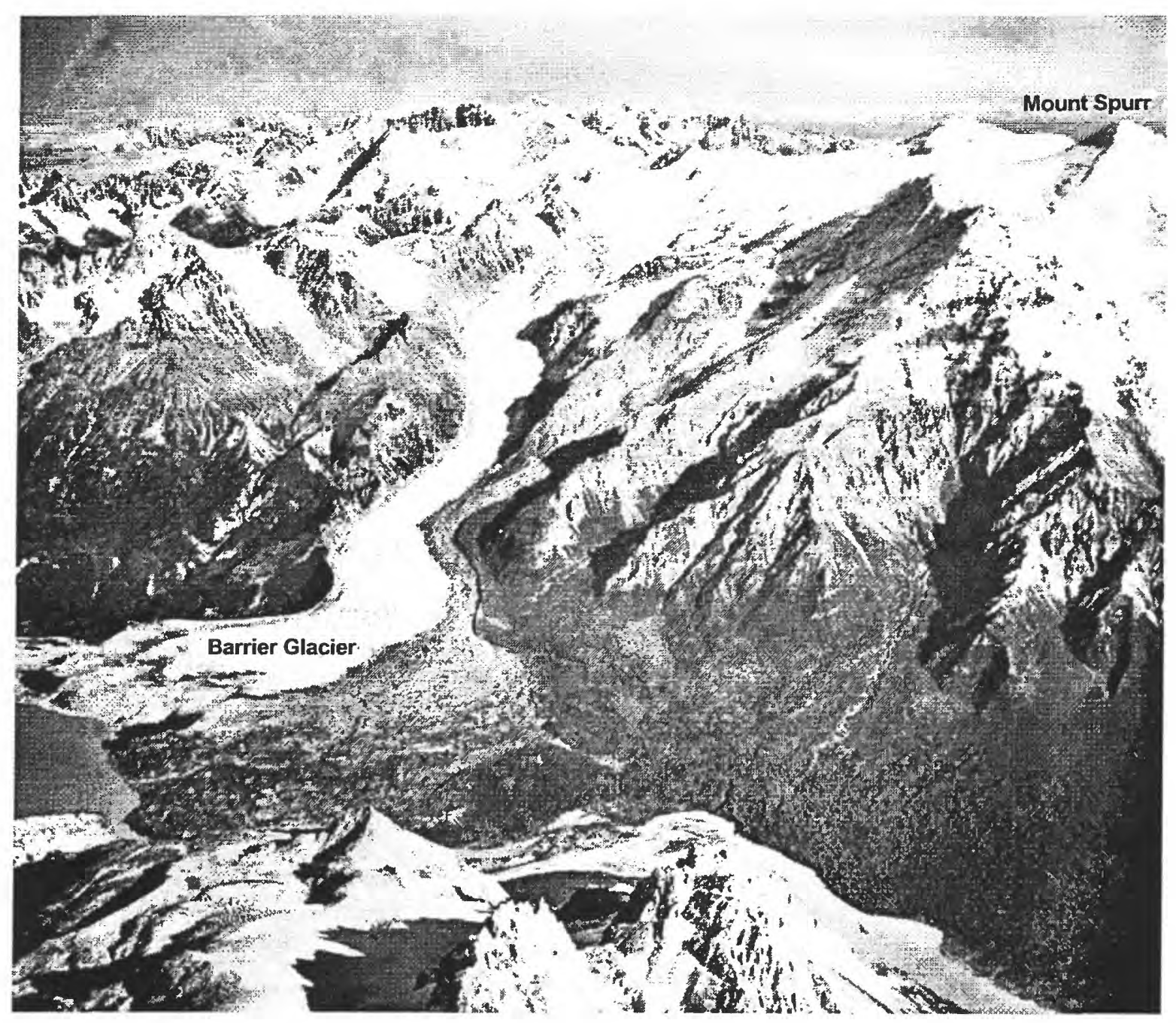

Figure 4. Mount Spurr Volcano seen from the southwest showing Barrier Glacier on September 4, 1966. The summit crater of Mount Spurr appears in the upper right. The eastern end of Chakachamna Lake (lower left) is dammed by the lower debris-covered portion of Barrier Glacier. Chakachatna River, draining Chakachamna Lake, flows east (left to right) across the bottom of the photo. (U.S. Geological Survey photograph by Austin Post, \#666-9.)

173 ice-thickness measurement points on Cascade volcanoes were greater than $200 \mathrm{kPa}$ and 5 percent were greater than $300 \mathrm{kPa}$ (Kennard, 1983).

None of the techniques considered for estimating ice thickness were fully satisfactory. Additionally, most of the area in which ice-thickness estimation was needed was high on the mountain and relatively steep. Where measurements had been made in this region, basal shear stresses were higher than the "normal" range and generally higher than the theoretically based relations predicted (that is, the measurements were outliers). Hence, the numerical estimation methods previously considered might not work well in much of the area where they were needed. 


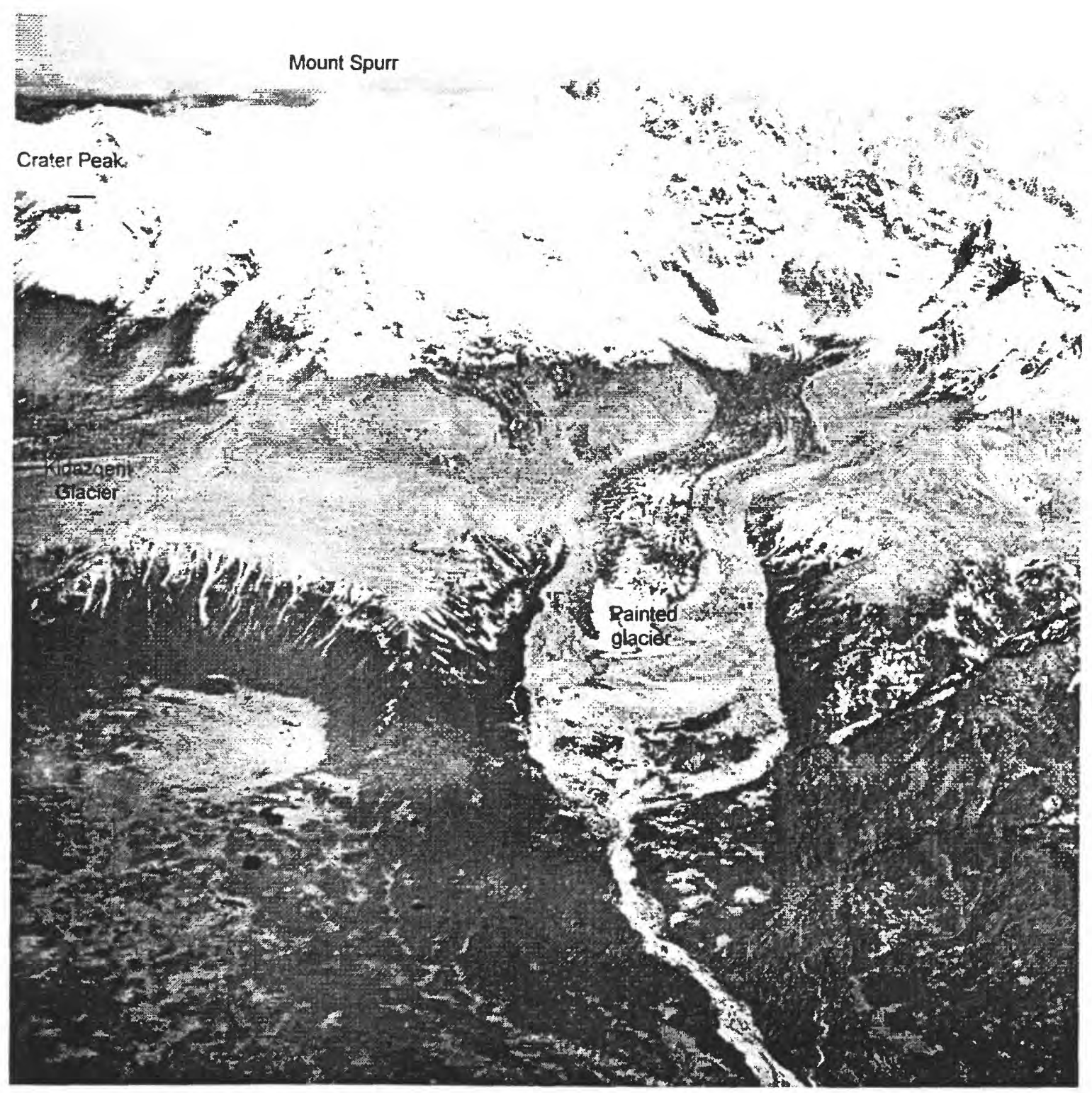

Figure 5. Mount Spurr Volcano seen from the southeast showing Painted glacier (informal name) on September 4, 1966, after a fresh snowfall above 1,200 meters. Both the summit crater, Mount Spurr, and the south flank crater, Crater Peak, which erupted in 1953 and 1992, can be seen in the upper left of the photo. The lower part of Painted glacier (center) is still heavily covered by ash from the 1953 eruption, as is Kidazqeni Glacier (center left). Small folds in the medial moraines indicate that Painted glacier is possibly a weak pulse-type glacier (Mayo, 1978). (U.S. Geological Survey photograph by Austin Post, \#666-4.) 


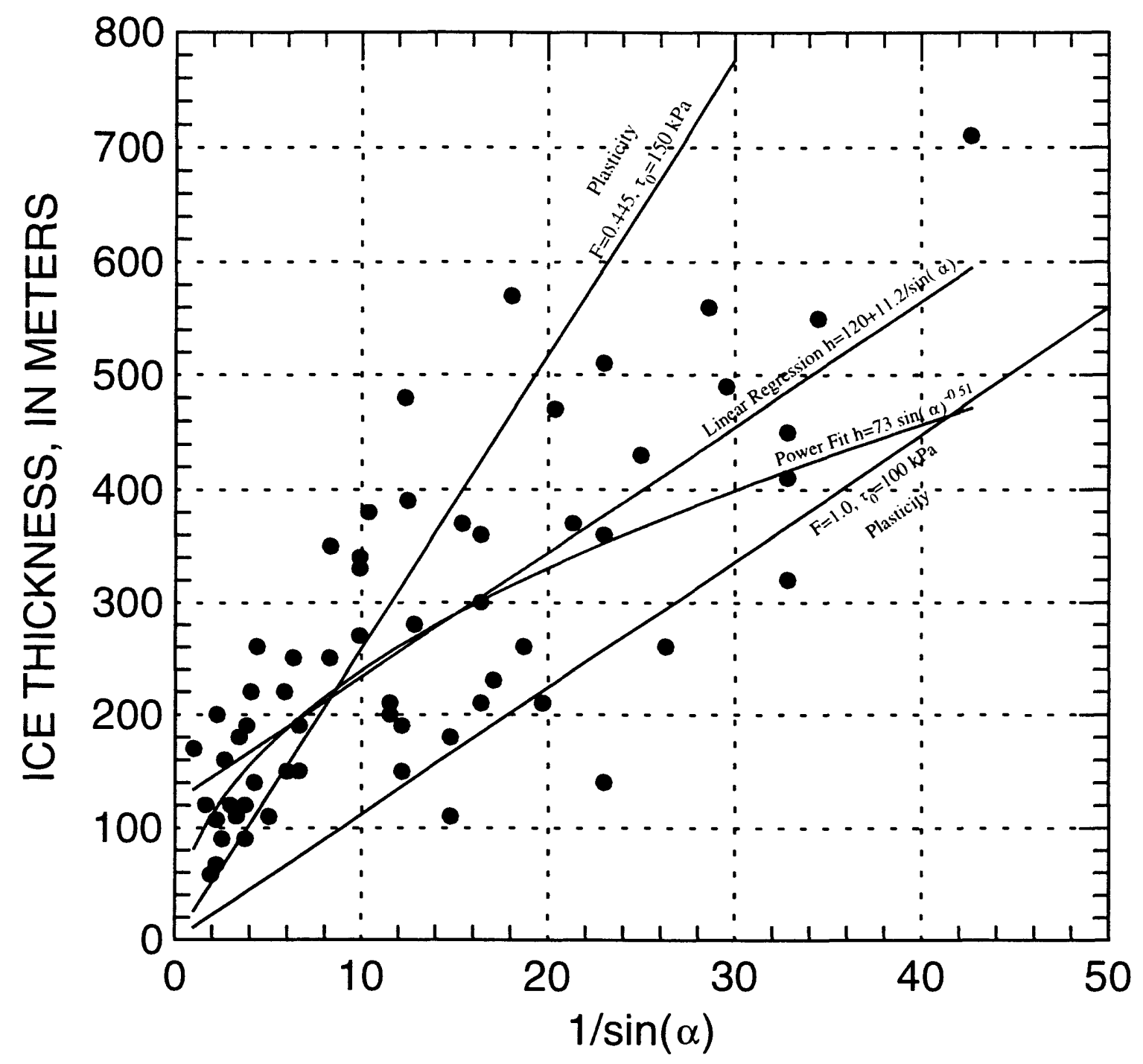

Figure 6. Scatter plot of measured ice thickness versus glacier surface slope. The normal upper and lower limits predicted by plasticity theory are shown (boundary parameters are as indicated). Also shown are the simple linear regression and the power curve fit which result from linear regression of the transformed variables, $\log (h)$ and $\log [1 / \sin (\alpha)]$.

Ice depths between and away from measurement points on Mount Spurr were determined by extrapolation from known points using interpretation of subglacial ridges, knobs, and depressions from stereo vertical air photography and topographic maps, continuity arguments (where possible), and the general principle that the topography of the glacier surface reflects the trend in basal topography and that the ice is thinner where the slope is steeper. Driedger and Kennard (1986a) give a detailed discussion of the inference of basal topography from ice-surface features and topography. 


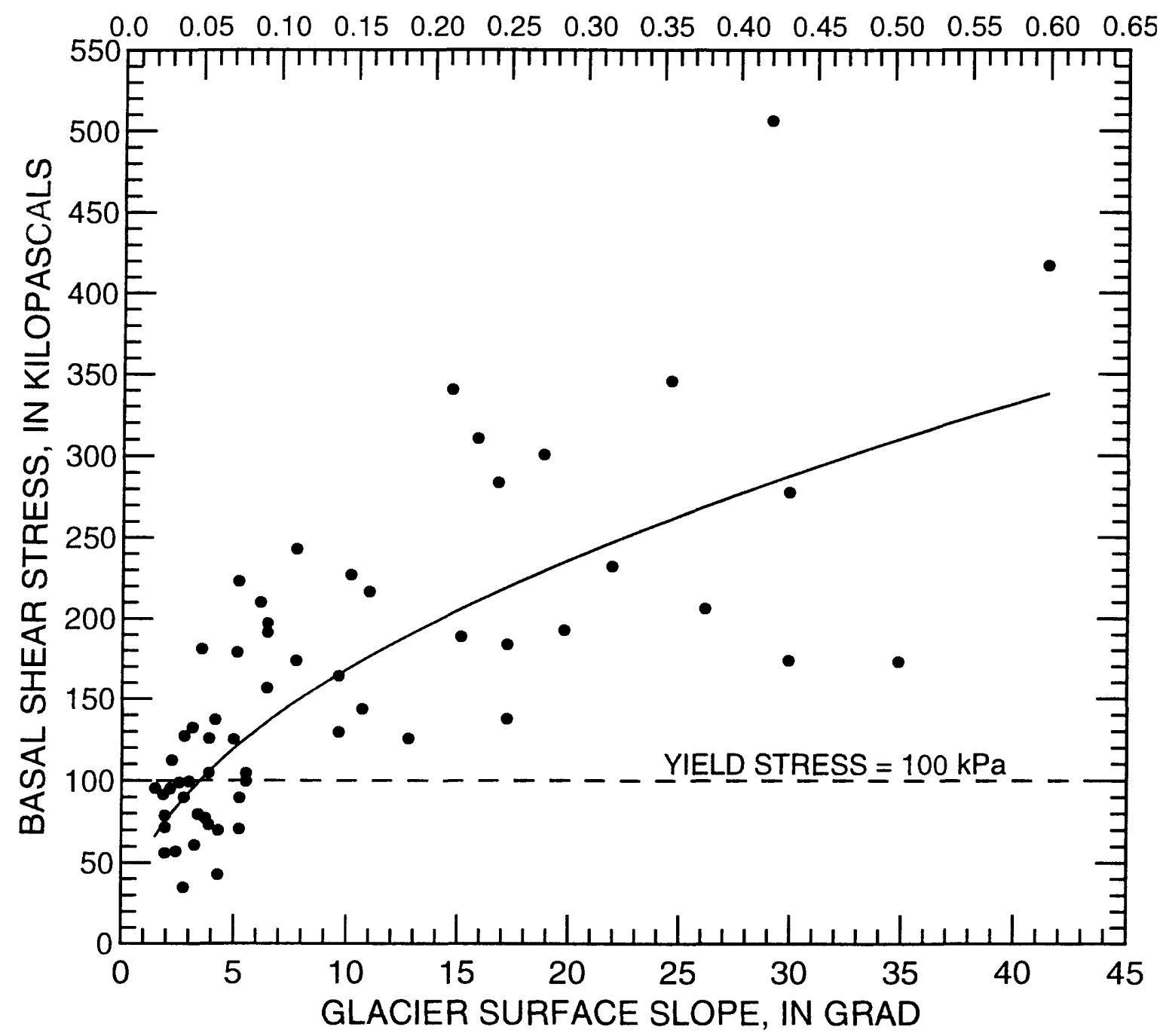

Figure 7. Scatter plot of basal shear stress versus glacier surface slope or sine of the glacier surface slope. Stresses were calculated using an estimated shape factor of 0.65. The plasticity assumption of a constant basal shear stress or "yield stress" of about $100 \mathrm{kPa}$ is shown by the dashed line. Although the fit is poor, the best relation is found between the basal shear stress and very nearly the square root of the sine of the glacier surface slope, $\tau_{b}=420[\sin (\alpha)]^{0.49}$, as shown by the power curve fit (solid line).

In some locations, changes in ice thickness up- or down-glacier from measurement points were inferred by applying a continuity of mass flux argument: the product of velocity and ice thickness is relatively constant over short distances. To use this technique, velocities were estimated from ogive spacing at 11 locations (fig. 8) on three apparently non-surge-type glaciers and one possibly weak pulse-type glacier (Painted glacier, fig. 5). Ogives are arcuate surface features extending across a glacier that can be either alternating bands of light and dark ice sometimes called "Forbes bands" or topographic waves that are referred to as "wave ogives" (Waddington, 1986). They form 
at the rate of one per year below some ice falls and travel down-glacier at the surface velocity of the ice. The distance between successive ogives represents an annual increment of ice motion. The wavelength of a wave ogive or the combined width (up- and down-glacier) of one light and one dark band represents the distance the ice travels in one year. Ogive spacing, and hence annual surface ice velocity, was observed on 1:40,000 scale U.S. Geological Survey vertical mapping photographs taken September 2, 1952.

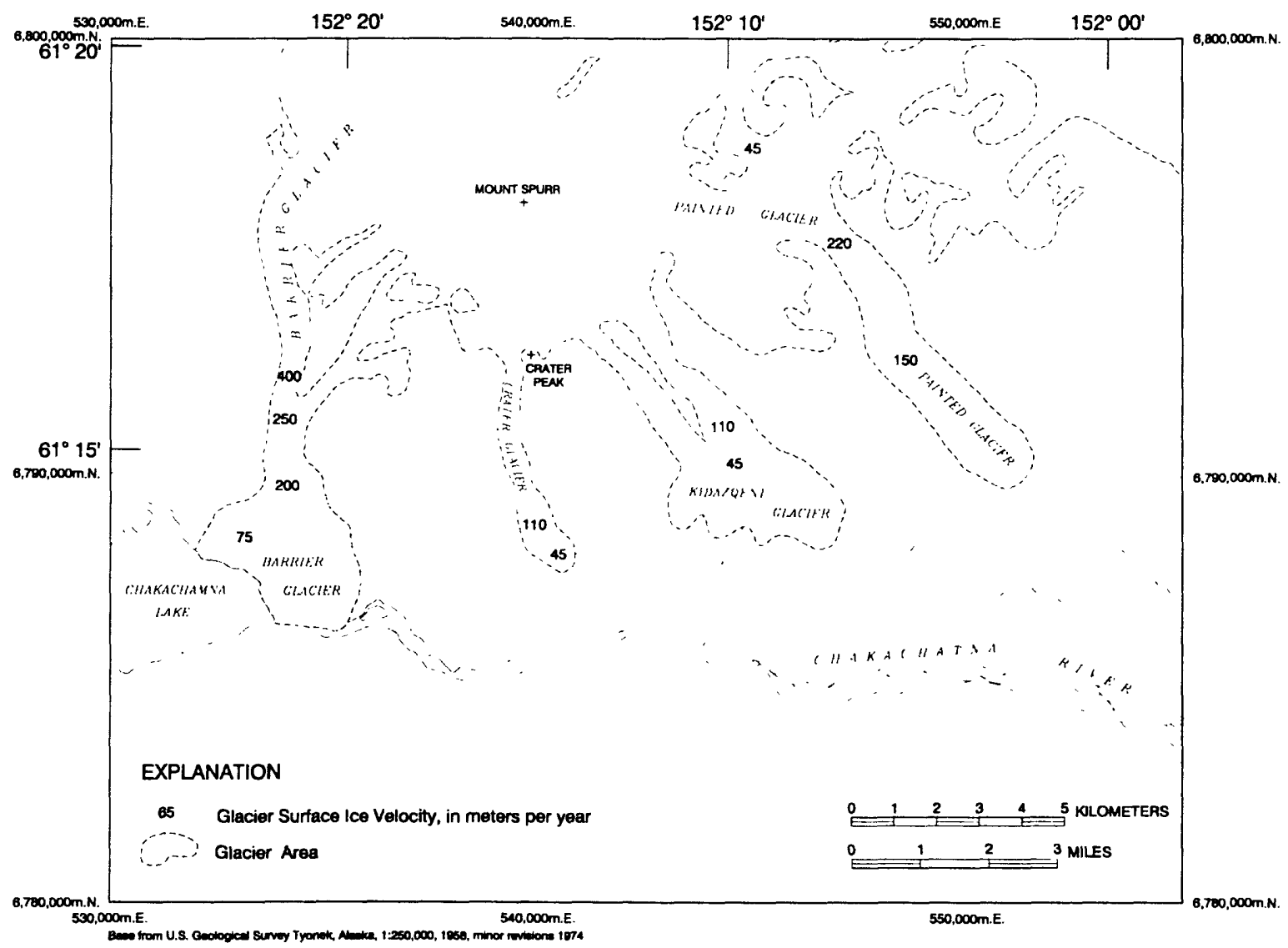

Figure 8. Horizontal surface ice velocities, in meters per year, derived from ogive spacings observed on 1:40,000 scale U.S. Geological Survey vertical mapping photographs taken September 2, 1952. Universal Transverse Mercator (UTM) Projection, Zone 5. 10,000 meter UTM, Zone 5 grid ticks shown around perimeter of map.

The same continuity argument can be used to some degree without knowing the velocity. For instance, if the glacier width and surface slope are the same at two nearby cross sections of a given glacier and the net surface balance between the sections is small, the ice thickness must be similar for continuity to be maintained. If the widths are the same but the slopes differ, the section with the steeper slope will be thinner than the section with the more gentle slope. 


\section{Seasonal Snow}

Seasonal snow was not measured for this study, but was estimated because it may contribute significantly to glaciovolcanic hazards. Seasonal snow covers almost all areas at Mount Spurr. The U.S. Soil Conservation Service (monthly reports, 1982-85) made measurements near Mount Spurr for the years 1982-85 (table 3). On the basis of these measurements, the average snowpack in nonglacier areas reaches a maximum of about $1.0 \mathrm{~m}$ water equivalent in April or May. Some of the non-glacier area may be too steep to support any seasonal snow, but it is assumed that this is compensated by areas where the maximum snowpack is greater than $1.0 \mathrm{~m}$ due to avalanching and wind redistribution. The average seasonal snowpack on the glaciers is expected to peak in May or June at about $2.0 \mathrm{~m}$ water equivalent on the basis of the approximate $2: 1$ ratio of glacier runoff to nonglacier (alpine) runoff in Gulkana and Wolverine glacier basins (Mayo, 1986).

Table 3. Seasonal snow data from U.S. Soil Conservation Service Sites near Mount Spurr. The average is the four-year average of the yearly maximum snowpack, in water equivalent, for the years $1982-1985$

[deg.. degrees: min.. minutes]

\begin{tabular}{|c|c|c|c|c|}
\hline $\begin{array}{c}\text { Soil Conservation } \\
\text { Service Snow Survey } \\
\text { Site }\end{array}$ & $\begin{array}{l}\text { Latitude } \\
\text { (deg. min.) }\end{array}$ & $\begin{array}{l}\text { Longitude } \\
\text { (deg. min.) }\end{array}$ & $\begin{array}{c}\text { Elevation } \\
\text { (meters) }\end{array}$ & $\begin{array}{c}\text { Average Maximum } \\
\text { Water Equivalent } \\
\text { (meters) }\end{array}$ \\
\hline Capps Plateau ${ }^{1}$ & $61^{\circ} 15^{\prime}$ & $151^{\circ} 48^{\prime}$ & 838 & 1.04 \\
\hline Chulitna Plateau ${ }^{2}$ & $61^{\circ} 13^{\prime}$ & $151^{\circ} 38^{\prime}$ & 469 & 0.62 \\
\hline
\end{tabular}

\section{SNOW AND ICE AREAS AND VOLUMES}

Snow and ice areas and volumes are tabulated by altitude and drainage basin (tables 4-12) to facilitate hazard assessments of floods and lahars which may result in part from snow and ice melt and erosion during an eruption or major landslide.

Although all runoff from the mountain quickly enters either the Chakachatna or the Chichantna River, the latter of which is a tributary of the Beluga River, seven sub-drainages (fig. 1 and plate 1) were defined for the purpose of separating areas that might contribute differently to hazards during an eruption. Where drainage divides are covered by glaciers, the glacier surface topography was used to define the ice divide. This definition may not always be correct. The drainage divide for subglacial water is controlled by a combination of the glacier surface and bed topography, although as long as the surface and bed slopes are comparable, the surface slope is the dominant factor (Paterson, 1981, p. 142). 
Table 4. Areas and volumes of snow and ice in Barrier Glacier sub-basin. Drainage boundaries are shown on figure 1 and plate 1

[ $\mathrm{km}^{2}$. square kilometers; $\mathrm{km}^{3}$, cubic kilometers]

\begin{tabular}{|c|c|c|c|c|c|c|c|c|c|}
\hline \multirow{2}{*}{$\begin{array}{l}\text { Surface } \\
\text { altitude } \\
\text { interval } \\
\text { (meters) }\end{array}$} & \multicolumn{5}{|c|}{ Ice depth interval (meters) } & \multicolumn{2}{|c|}{ Seasonal minimum } & \multicolumn{2}{|c|}{ Seasonal maximum } \\
\hline & 0 & $0-100$ & $100-200$ & $200-300$ & $\begin{array}{l}300-400400-500 \quad 500-600600-700700-800 \\
\text { Area }\left(\mathrm{km}^{2}\right)\end{array}$ & $\begin{array}{l}\text { Area } \\
\left(\mathrm{km}^{2}\right)\end{array}$ & $\begin{array}{c}\text { Volume } \\
\left(\mathrm{km}^{3}\right)\end{array}$ & $\begin{array}{l}\text { Area } \\
\left(\mathrm{km}^{2}\right)\end{array}$ & $\begin{array}{c}\text { Volume } \\
\left(\mathrm{km}^{3}\right)\end{array}$ \\
\hline $200-400$ & & 1.31 & 0.06 & & & 1.37 & 0.07 & 1.37 & 0.07 \\
\hline $400-600$ & 0.25 & 2.38 & 2.56 & 2.88 & & 7.82 & 1.22 & 8.07 & 1.24 \\
\hline $600-800$ & 0.94 & 0.25 & 0.50 & 0.56 & 0.31 & 1.62 & 0.34 & 2.56 & 0.34 \\
\hline $800-1000$ & 1.06 & 0.38 & 0.44 & 0.13 & & 0.95 & 0.12 & 2.01 & 0.12 \\
\hline $1000-1200$ & 1.38 & 0.38 & 0.44 & & & 0.82 & 0.09 & 2.20 & 0.09 \\
\hline $1200-1400$ & 1.38 & 0.63 & 0.50 & & & 1.13 & 0.11 & 2.51 & 0.11 \\
\hline $1400-1600$ & 1.31 & 0.81 & 0.69 & & & 1.50 & 0.14 & 2.81 & 0.14 \\
\hline $1600-1800$ & 1.19 & 0.94 & 0.75 & & & 1.69 & 0.16 & 2.88 & 0.16 \\
\hline $1800-2000$ & 1.38 & 0.56 & 1.19 & & & 1.75 & 0.21 & 3.13 & 0.21 \\
\hline $2000-2200$ & 1.25 & 0.63 & 1.44 & 0.44 & & 2.51 & 0.36 & 3.76 & 0.37 \\
\hline $2200-2400$ & 0.81 & 0.75 & 1.50 & 1.25 & & 3.50 & 0.58 & 4.31 & 0.59 \\
\hline $2400-2600$ & 0.75 & 0.69 & 3.63 & 0.44 & & 4.76 & 0.69 & 5.51 & 0.70 \\
\hline $2600-2800$ & 0.25 & 0.50 & 5.50 & & & 6.00 & 0.85 & 6.25 & 086 \\
\hline $2800-3000$ & & 0.75 & 3.44 & 0.19 & & 4.38 & 0.60 & 4.38 & 0.61 \\
\hline $3000-3200$ & & 0.19 & 0.19 & & & 0.38 & 0.04 & 0.38 & 0.04 \\
\hline $3200-3400$ & & 0.06 & & & & 0.06 & 0.00 & 0.06 & 0.00 \\
\hline Totals & 12.0 & & & & & 40.2 & 5.6 & 52.2 & 5.7 \\
\hline \multicolumn{2}{|c|}{ Average ice depth $=$} & 139 & meters & & & & & & \\
\hline
\end{tabular}

Table 5. Areas and volumes of snow and ice in Painted glacier sub-basin (informal name). Drainage boundaries are shown on figure 1 and plate 1

[ $\mathrm{km}^{2}$, square kilometers; $\mathrm{km}^{3}$, cubic kilometers]

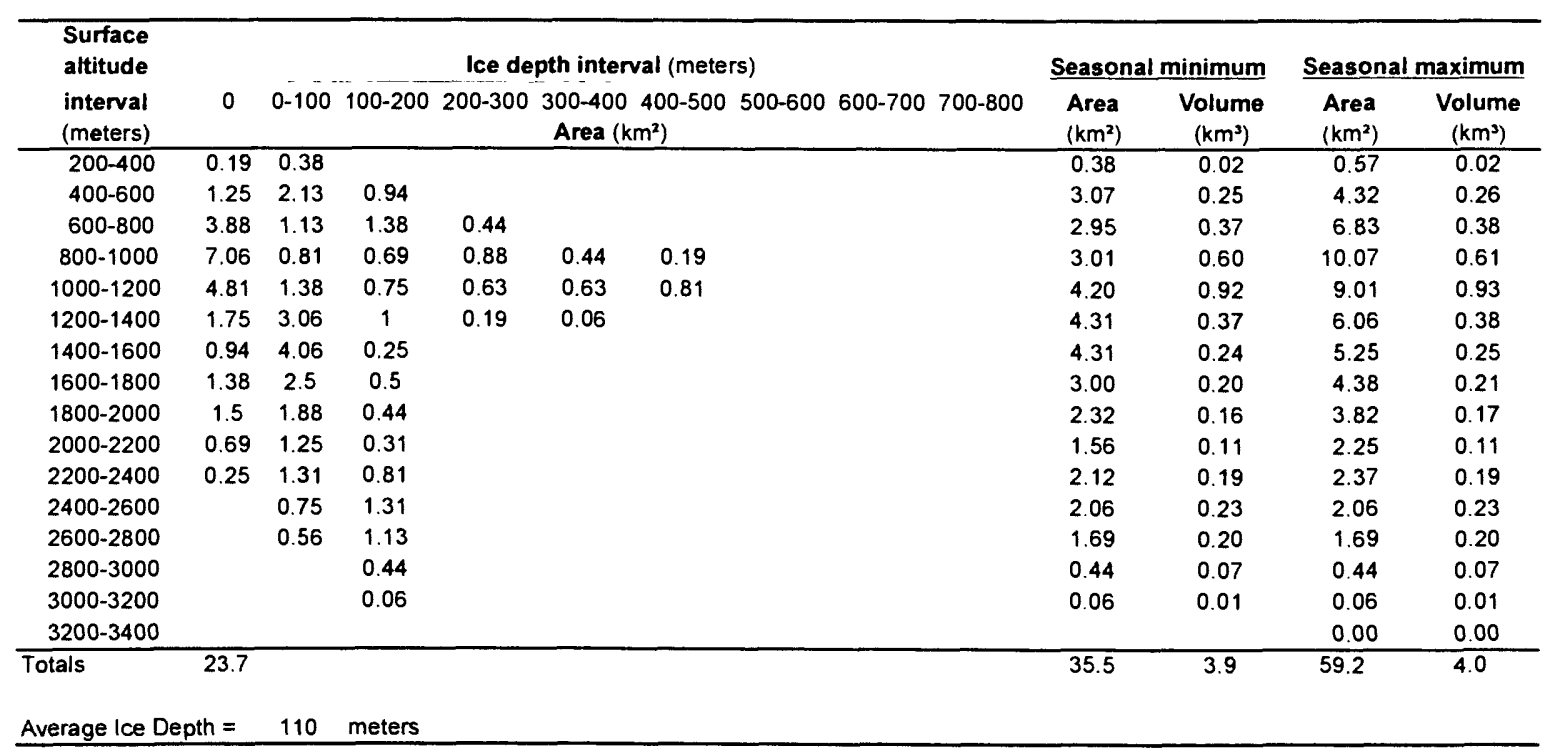


Table 6. Areas and volumes of snow and ice in west Kidazqeni Glacier sub-basin. Drainage boundaries are shown on figure 1 and piate 1 [ $\mathrm{km}^{2}$, square kilometers: $\mathrm{km}^{3}$. cubic kilometers]

\begin{tabular}{|c|c|c|c|c|c|c|c|c|}
\hline \multirow{2}{*}{$\begin{array}{l}\text { Surface } \\
\text { altitude } \\
\text { interval } \\
\text { (meters) }\end{array}$} & \multirow[b]{2}{*}{0} & \multicolumn{3}{|r|}{ Ice depth interval (meters) } & \multicolumn{2}{|c|}{ Seasonal minimum } & \multicolumn{2}{|c|}{ Seasonal maximum } \\
\hline & & $0-100$ & $100-200$ & 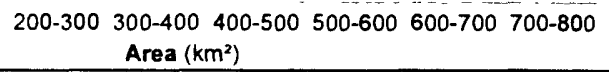 & $\begin{array}{l}\text { Area } \\
\left(\mathrm{km}^{2}\right)\end{array}$ & $\begin{array}{c}\text { Volume } \\
\left(\mathrm{km}^{3}\right)\end{array}$ & $\begin{array}{l}\text { Area } \\
\left(\mathrm{km}^{2}\right)\end{array}$ & $\begin{array}{l}\text { Volume } \\
\left(\mathrm{km}^{3}\right)\end{array}$ \\
\hline $200-400$ & & & & & & & 0.00 & 0.00 \\
\hline $400-600$ & & & & & & & 0.00 & 0.00 \\
\hline $600-800$ & & 0.69 & 013 & & 0.82 & 0.05 & 0.82 & 0.05 \\
\hline $800-1000$ & 0.06 & 0.44 & 0.63 & 0.06 & 1.13 & 0.13 & 1.19 & 0.13 \\
\hline $1000-1200$ & 0.13 & 0.25 & 019 & 0.06 & 0.50 & 0.06 & 0.63 & 0.06 \\
\hline $1200-1400$ & 0.19 & 0.19 & 013 & & 0.32 & 0.03 & 0.51 & 0.03 \\
\hline $1400-1600$ & 0.25 & 0.06 & 019 & & 0.25 & 0.03 & 0.50 & 0.03 \\
\hline $1600-1800$ & 0.31 & 0.06 & 0.19 & & 0.25 & 0.03 & 0.56 & 0.03 \\
\hline $1800-2000$ & 038 & 0.06 & 0.19 & & 0.25 & 0.03 & 0.63 & 0.03 \\
\hline $2000-2200$ & 0.25 & 0.13 & 0.56 & 050 & 1.19 & 0.22 & 1.44 & 0.22 \\
\hline $2200-2400$ & 0.13 & & 056 & & 0.56 & 0.08 & 0.69 & 0.08 \\
\hline $2400-2600$ & & & 050 & & 0.50 & 0.08 & 0.50 & 0.08 \\
\hline $2600-2800$ & & & 031 & & 0.31 & 0.05 & 0.31 & 0.05 \\
\hline $2800-3000$ & & 0.13 & 013 & & 0.26 & 0.03 & 0.26 & 0.03 \\
\hline $3000-3200$ & & 0.06 & & & 0.06 & 0.00 & 0.06 & 0.00 \\
\hline $3200-3400$ & & 0.06 & & & 0.06 & 0.00 & 0.06 & 0.00 \\
\hline Totals & 1.7 & & & & 6.5 & 0.8 & 8.2 & 0.8 \\
\hline \multicolumn{2}{|c|}{ Average lce Depth = } & 123 & meters & & & & & \\
\hline
\end{tabular}

Table 7. Areas and volumes of snow and ice in east Kidazqeni Glacier sub-basin. Drainage boundaries are shown on figure 1 and plate 1

$\left[\mathrm{km}^{2}\right.$, square kilometers: $\mathrm{km}^{3}$. cubic kilometers]

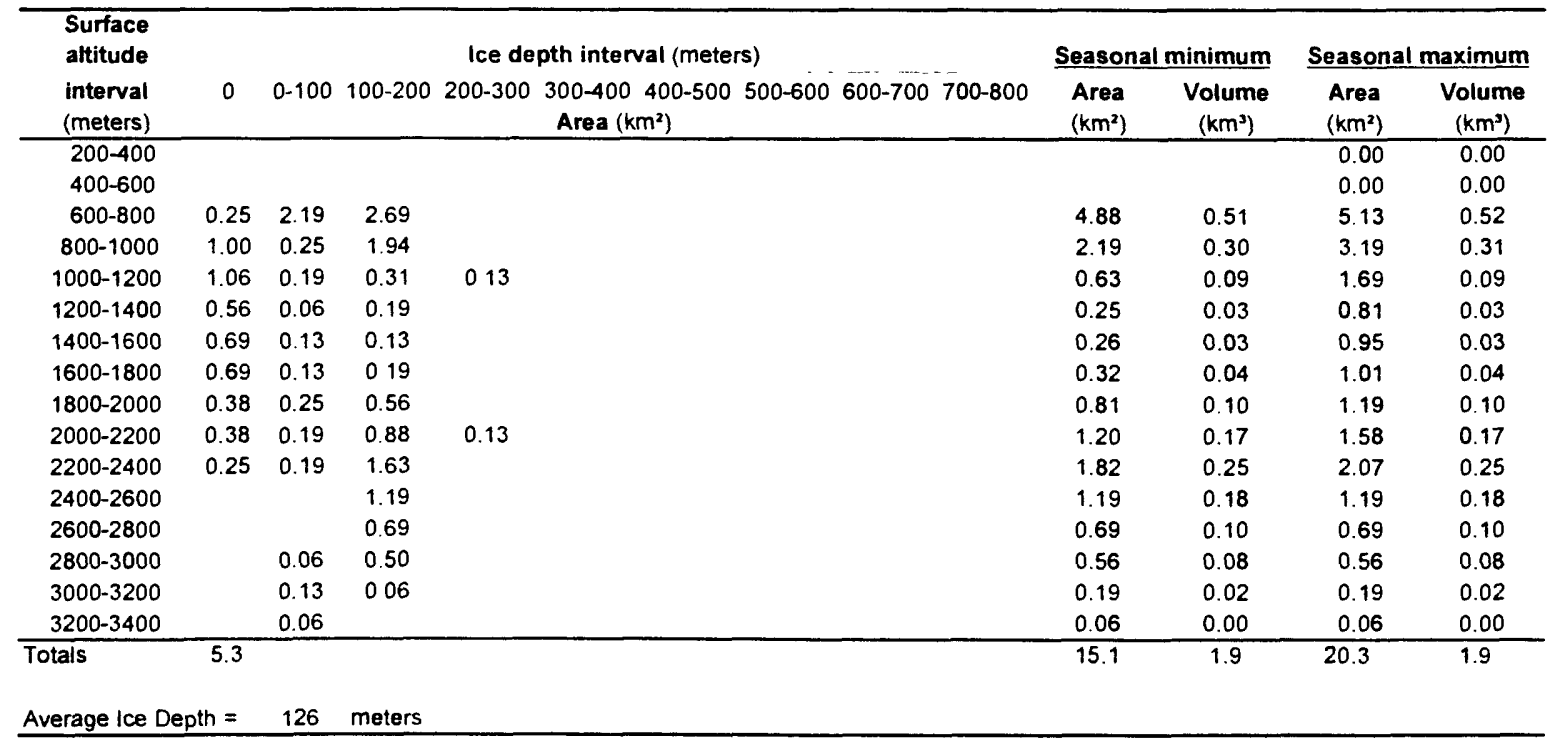


Table 8. Areas and volumes of snow and ice in Crater glacier sub-basin (informal name). Drainage boundaries are shown on figure 1 and plate 1

[ $\mathrm{km}^{2}$. square kilometers: $\mathrm{km}^{3}$, cubic kilometers]

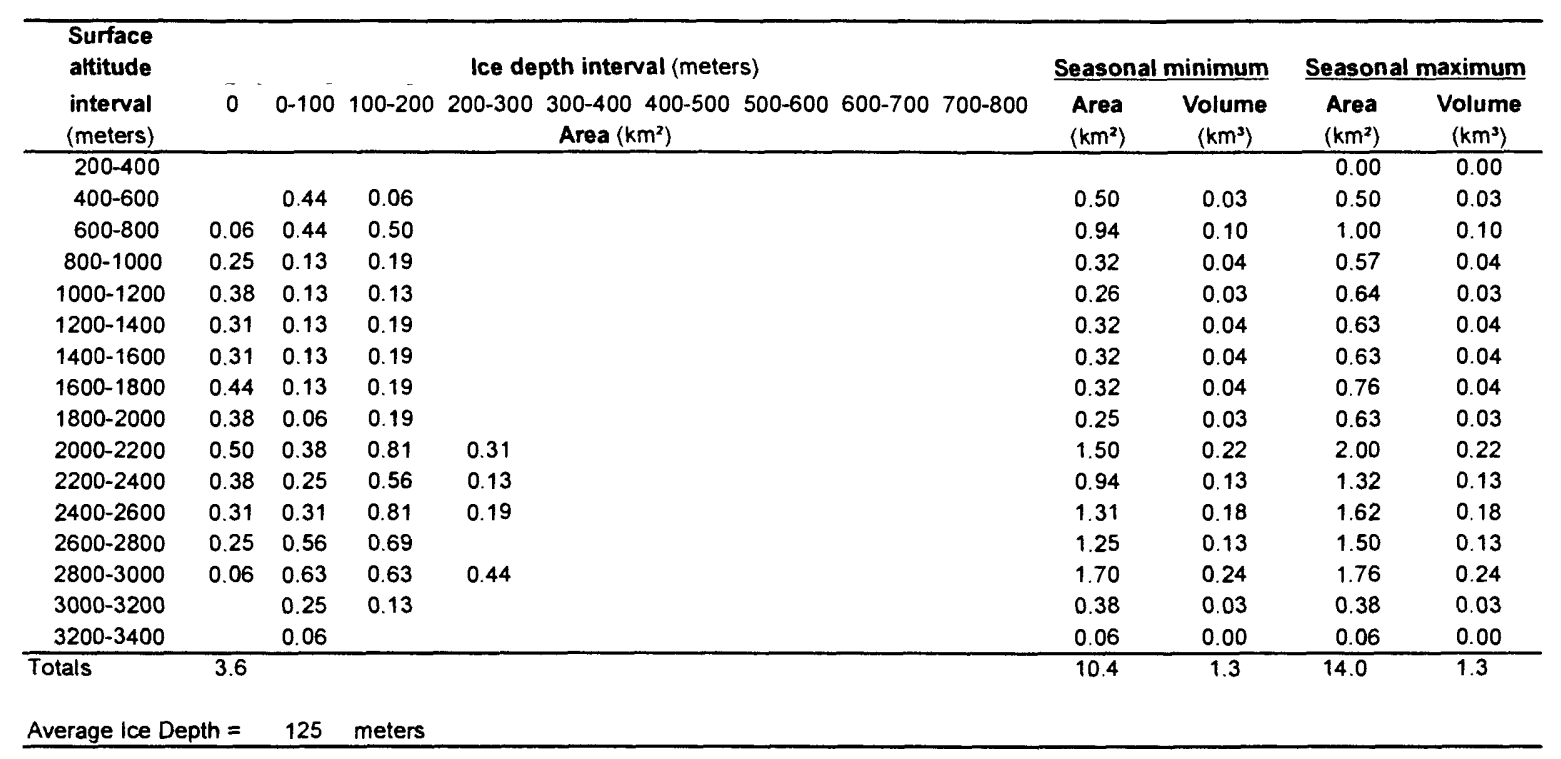

Table 9. Areas and volumes of snow and ice in South branch (informal name), Capps Glacier sub-basin. Drainage boundaries are shown on figure 1 and plate 1

$\left[\mathrm{km}^{2}\right.$, square kilometers: $\mathrm{km}^{3}$, cubic kilometers]

\begin{tabular}{|c|c|c|c|c|c|c|c|c|c|c|c|}
\hline \multirow{2}{*}{$\begin{array}{l}\text { Surface } \\
\text { altitude } \\
\text { interval } \\
\text { (meters) }\end{array}$} & \multicolumn{7}{|c|}{ Ice depth interval (meters) } & \multicolumn{2}{|c|}{ Seasonal minimum } & \multicolumn{2}{|c|}{ Seasonal maximum } \\
\hline & 0 & $0-100$ & \multicolumn{4}{|c|}{ Area $\left(\mathrm{km}^{2}\right)$} & $500-600600-700700-800$ & $\begin{array}{l}\text { Area } \\
\left(\mathrm{km}^{2}\right)\end{array}$ & $\begin{array}{c}\text { Volume } \\
\left(\mathrm{km}^{3}\right)\end{array}$ & $\begin{array}{l}\text { Area } \\
\left(\mathrm{km}^{2}\right)\end{array}$ & $\begin{array}{c}\text { Volume } \\
\left(\mathrm{km}^{3}\right)\end{array}$ \\
\hline $200-400$ & & & & & & & & 0.00 & 0.00 & 0.00 & 0.00 \\
\hline $400-600$ & & & & & & & & 0.00 & 0.00 & 0.00 & 0.00 \\
\hline $600-800$ & & & & & & & & 0.00 & 0.00 & 0.00 & 0.00 \\
\hline $800-1000$ & & & & & & & & 0.00 & 0.00 & 0.00 & 0.00 \\
\hline $1000-1200$ & 0.25 & 0.25 & 0.75 & 0.50 & 2.00 & & & 3.50 & 0.95 & 3.75 & 0.96 \\
\hline $1200-1400$ & 0.50 & 1.25 & 0.75 & 1.25 & 1.25 & & & 4.50 & 0.93 & 5.00 & 0.94 \\
\hline $1400-1600$ & 0.75 & 1.50 & 1.50 & 0.25 & & & & 3.25 & 0.36 & 4.00 & 0.37 \\
\hline $1600-1800$ & 0.75 & 1.25 & 1.75 & & & & & 3.00 & 0.33 & 3.75 & 0.34 \\
\hline $1800-2000$ & 0.50 & 1.50 & 0.75 & & & & & 2.25 & 0.19 & 2.75 & 0.20 \\
\hline $2000-2200$ & 0.75 & 1.50 & 1.00 & & & & & 2.50 & 0.23 & 3.25 & 0.24 \\
\hline $2200-2400$ & 0.25 & 0.75 & 0.75 & & & & & 1.50 & 0.15 & 1.75 & 0.15 \\
\hline $2400-2600$ & & 1.75 & 1.00 & & & & & 2.75 & 0.24 & 2.75 & 0.25 \\
\hline $2600-2800$ & & 0.00 & 1.25 & & 0.25 & 0.25 & & 1.75 & 0.39 & 1.75 & 0.39 \\
\hline $2800-3000$ & & 1.00 & 1.50 & 0.75 & 1.50 & 1.50 & 0.25 & 6.50 & 1.80 & 6.50 & 1.81 \\
\hline $3000-3200$ & & 0.50 & 0.50 & & & & & 1.00 & 0.10 & 1.00 & 0.10 \\
\hline $3200-3400$ & & 0.25 & & & & & & 0.25 & 0.01 & 0.25 & 0.01 \\
\hline Totals & 3.8 & & & & & & & 32.8 & 5.7 & 36.5 & 5.8 \\
\hline Average lce $D$ & oth $=$ & 174 & meters & & & & & & & & \\
\hline
\end{tabular}


Table 10. Areas and volumes of snow and ice in Main branch, Capps Glacier sub-basin. Drainage boundaries are shown on figure 1 and plate 1

$\left[\mathrm{km}^{2}\right.$. square kilometers: $\mathrm{km}^{3}$. cubic kilometers]

\begin{tabular}{|c|c|c|c|c|c|c|c|c|c|c|c|c|c|}
\hline \multirow{2}{*}{$\begin{array}{l}\text { Surface } \\
\text { altitude } \\
\text { interval } \\
\text { (meters) }\end{array}$} & \multicolumn{9}{|c|}{ Ice depth interval (meters) } & \multicolumn{2}{|c|}{ Seasonal minimum } & \multicolumn{2}{|c|}{ Seasonal maximum } \\
\hline & 0 & $0-100$ & $100-200$ & $200-300$ & $\begin{array}{r}300-400 \\
\text { Area }(\mathrm{k}\end{array}$ & $\begin{array}{l}400-500 \\
\left.m^{2}\right)\end{array}$ & $500-600$ & $600-700$ & $700-800$ & $\begin{array}{l}\text { Area } \\
\left(\mathrm{km}^{2}\right)\end{array}$ & $\begin{array}{c}\text { Volume } \\
\left(\mathrm{km}^{3}\right)\end{array}$ & $\begin{array}{l}\text { Area } \\
\left(\mathrm{km}^{2}\right)\end{array}$ & $\begin{array}{c}\text { Volume } \\
\left(\mathrm{km}^{3}\right)\end{array}$ \\
\hline $200-400$ & & 12.00 & 15.25 & 350 & & & & & & 30.75 & 3.76 & 30.75 & 3.82 \\
\hline $400-600$ & 3.75 & 1.75 & 5.25 & 1225 & 800 & 5.00 & 1.00 & & & 33.25 & 9.54 & 37.00 & 9.61 \\
\hline $600-800$ & 7.00 & 2.50 & 2.50 & 1.00 & 2.75 & 2.00 & 5.00 & 2.75 & 1.50 & 20.00 & 8.28 & 27.00 & 8.33 \\
\hline $800-1000$ & 900 & 1.25 & 2.50 & 150 & 4.00 & 4.25 & 4.75 & 1.00 & & 19.25 & 7.39 & 28.25 & 7.44 \\
\hline $1000-1200$ & 9.25 & 400 & 275 & 225 & 275 & 5.25 & & & & 17.00 & 4.50 & 26.25 & 4.54 \\
\hline $1200-1400$ & 4.50 & 800 & 5.25 & 275 & 4.00 & 200 & 1.00 & & & 23.00 & 4.73 & 27.50 & 4.78 \\
\hline $1400-1600$ & 5.00 & 650 & 550 & 275 & 1.75 & 0.75 & 0.25 & & & 17.50 & 2.93 & 22.50 & 2.97 \\
\hline $1600-1800$ & 375 & 8.25 & 4.75 & 225 & 0.50 & & & & & 15.75 & 1.86 & 19.50 & 1.90 \\
\hline $1800-2000$ & 3.25 & 575 & 3.25 & 075 & & & & & & 9.75 & 0.96 & 13.00 & 0.98 \\
\hline $2000-2200$ & 250 & 3.25 & 5.25 & & & & & & & 8.50 & 0.95 & 11.00 & 0.97 \\
\hline $2200-2400$ & 250 & 1.75 & 4.00 & & & & & & & 5.75 & 0.69 & 8.25 & 0.70 \\
\hline $2400-2600$ & 1.00 & 0.75 & 3.50 & & & & & & & 4.25 & 0.56 & 5.25 & 0.57 \\
\hline $2600-2800$ & 0.75 & 1.00 & 325 & & & & & & & 4.25 & 0.54 & 5.00 & 0.55 \\
\hline $2800-3000$ & & 0.75 & 3.25 & & & & & & & 4.00 & 0.53 & 4.00 & 0.54 \\
\hline $3000-3200$ & 0.50 & 0.50 & 0.75 & & & & & & & 1.25 & 0.14 & 1.75 & 014 \\
\hline $3200-3400$ & & 0.25 & 0.75 & & & & & & & 1.00 & 0.13 & 1.00 & 013 \\
\hline Totals & 52.8 & & & & & & & & & 215.3 & 47.5 & 268.0 & 48.0 \\
\hline
\end{tabular}

Table 11. Areas and volumes of snow and ice in Capps Glacier sub-basin. Drainage boundaries are shown on figure 1 and plate 1

[km² square kilometers: $\mathrm{km}^{3}$, cubic kilometers]

\begin{tabular}{|c|c|c|c|c|c|c|c|c|c|c|c|c|c|}
\hline \multirow{2}{*}{$\begin{array}{l}\text { Surface } \\
\text { altitude } \\
\text { interval } \\
\text { (meters) }\end{array}$} & \multicolumn{9}{|c|}{ Ice depth interval (meters) } & \multicolumn{2}{|c|}{ Seasonal minimum } & \multicolumn{2}{|c|}{ Seasonal maximum } \\
\hline & 0 & $0-100$ & $100-200$ & $200-300$ & $\begin{array}{c}300-400 \\
\text { Area }(\mathrm{kr}\end{array}$ & $\begin{array}{l}400-500 \\
\left.m^{2}\right)\end{array}$ & $500-600$ & $600-700$ & $700-800$ & $\begin{array}{l}\text { Area } \\
\left(\mathrm{km}^{2}\right)\end{array}$ & $\begin{array}{c}\text { Volume } \\
\left(\mathrm{km}^{3}\right)\end{array}$ & $\begin{array}{l}\text { Area } \\
\left(\mathrm{km}^{2}\right)\end{array}$ & $\begin{array}{c}\text { Volume } \\
\left(\mathrm{km}^{3}\right)\end{array}$ \\
\hline $200-400$ & & 12.00 & 15.25 & 3.50 & & & & & & 30.75 & 3.76 & 30.75 & 3.82 \\
\hline $400-600$ & 3.75 & 1.75 & 5.25 & 12.25 & 8.00 & 5.00 & 1.00 & & & 33.25 & 9.54 & 37.00 & 9.61 \\
\hline $600-800$ & 7.00 & 2.50 & 2.50 & 1.00 & 2.75 & 2.00 & 5.00 & 2.75 & 1.50 & 20.00 & 8.28 & 27.00 & 8.33 \\
\hline $800-1000$ & 9.00 & 1.25 & 2.50 & 1.50 & 400 & 4.25 & 4.75 & 1.00 & & 19.25 & 7.39 & 28.25 & 744 \\
\hline $1000-1200$ & 9.50 & 4.25 & 3.50 & 275 & 4.75 & 5.25 & & & & 20.50 & 5.45 & 30.00 & 5.50 \\
\hline $1200-1400$ & 5.00 & 9.25 & 6.00 & 4.00 & 5.25 & 2.00 & 1.00 & & & 27.50 & 5.65 & 32.50 & 5.71 \\
\hline $1400-1600$ & 575 & 8.00 & 7.00 & 3.00 & 1.75 & 0.75 & 0.25 & & & 20.75 & 3.29 & 26.50 & 3.34 \\
\hline $1600-1800$ & 4.50 & 9.50 & 6.50 & 2.25 & 050 & & & & & 18.75 & 2.19 & 23.25 & 2.23 \\
\hline $1800-2000$ & 3.75 & 7.25 & 4.00 & 0.75 & & & & & & 12.00 & 1.15 & 15.75 & 1.18 \\
\hline $2000-2200$ & 3.25 & 4.75 & 6.25 & & & & & & & 11.00 & 1.18 & 14.25 & 1.21 \\
\hline $2200-2400$ & 2.75 & 2.50 & 4.75 & & & & & & & 7.25 & 0.84 & 10.00 & 0.86 \\
\hline $2400-2600$ & 1.00 & 2.50 & 4.50 & & & & & & & 7.00 & 0.80 & 8.00 & 0.82 \\
\hline $2600-2800$ & 0.75 & 1.00 & 4.50 & & 0.25 & 0.25 & & & & 6.00 & 0.93 & 6.75 & 0.94 \\
\hline $2800-3000$ & & 1.75 & 4.75 & 0.75 & 1.50 & 1.50 & 0.25 & & & 10.50 & 2.33 & 10.50 & 2.35 \\
\hline $3000-3200$ & 0.50 & 1.00 & 1.25 & & & & & & & 2.25 & 0.24 & 2.75 & 0.25 \\
\hline $3200-3400$ & & 0.50 & 0.75 & & & & & & & 1.25 & 0.14 & 1.25 & 0.14 \\
\hline Totals & 56.5 & & & & & & & & & 248.0 & 53.2 & 304.5 & 53.7 \\
\hline Average Ice D & $\operatorname{th}=$ & 210 & meters & & & & & & & & & & \\
\hline
\end{tabular}


Table 12. Summary of areas and volumes of snow and ice on Mount Spurr and their seasonal minimums and maximums. Drainage boundaries are shown on figure 1 and plate 1

$\left[\mathrm{km}^{2}\right.$. square kilometers: $\mathrm{km}^{3}$, cubic kilometers]

\begin{tabular}{lcccc}
\hline Glacier/Drainage Name & \multicolumn{3}{c}{ Seasonal Minimum } & \multicolumn{3}{c}{ Seasonal Maximum } \\
\cline { 2 - 3 } & $\begin{array}{c}\text { Area } \\
\left(\mathrm{km}^{2}\right)\end{array}$ & $\begin{array}{c}\text { Volume } \\
\left(\mathrm{km}^{3}\right)\end{array}$ & $\begin{array}{c}\text { Area } \\
\left(\mathrm{km}^{2}\right)\end{array}$ & $\begin{array}{c}\text { Volume } \\
\left(\mathrm{km}^{3}\right)\end{array}$ \\
\hline Chakachatna River drainage: & 40.2 & 5.6 & 52.2 & 5.7 \\
$\quad$ Barrier Glacier & 10.4 & 1.3 & 14.0 & 1.3 \\
Crater glacier & 6.5 & 0.8 & 8.2 & 0.8 \\
West Kidazqeni Glacier & 15.1 & 1.9 & 20.3 & 1.9 \\
East Kidazqeni Glacier & 35.5 & 3.9 & 59.2 & 4.0 \\
Painted glacier & 107.7 & 13.5 & 153.9 & 13.7 \\
Sub-Total & & & & \\
Chichantna River drainage: & 215.3 & 47.5 & 268.0 & 48.0 \\
Capps Glacier, Main branch & 32.8 & 5.7 & 36.5 & 5.8 \\
Capps Glacier, South branch & 248.1 & 53.2 & 304.5 & 53.8 \\
Sub-Total & & & & \\
& 355.8 & 66.7 & 458.4 & 67.5 \\
\hline
\end{tabular}

Each drainage basin was divided into surface altitude zones of $200 \mathrm{~m}$. Within each surface altitude zone, the areas with snow and ice thicknesses of 0 (non-glacier or alpine areas), 0-100, 100-200, 200-300 m, etc., were summed separately (tables 4-11) using the ice-thickness contours on plate 2. Areas were measured by counting cells of a grid overlaid on the ice-thickness map, a method that we believe is more repeatable than planimetering. A cell size of $1 / 4 \mathrm{~km}^{2}$ was used for Capps Glacier and $1 / 16 \mathrm{~km}^{2}$ elsewhere. Summed seasonal minimum areas correspond to the glacier areas and summed seasonal maximum areas correspond to the total of both glacier and alpine areas. Seasonal minimum volumes were obtained by multiplying snow and ice areas by their average thicknesses (assumed to be $50 \mathrm{~m}$ for thicknesses of 0-100 m, $150 \mathrm{~m}$ for thicknesses of 100-200 $\mathrm{m}$, etc.). Seasonal maximum volumes result from summing the minimum volumes with the estimated $1 \mathrm{~m}$ water equivalent of seasonal off-glacier snow and $2 \mathrm{~m}$ water equivalent of seasonal onglacier snow.

The areas and volumes of snow and ice on Mount Spurr are summarized in table 12. Overall it was necessary to estimate the snow and ice thickness over approximately 50 percent of the glacier area. Although the error in the estimated snow and ice thickness at specific locations may be quite large, the error in cumulative estimated volumes is approximately 40 percent, and for total combined estimated and measured volumes, about 25 percent. 


\section{DISCUSSION}

\section{Selected Subglacial Features}

Subglacial topography at Mount Spurr Volcano (plate 1) has several closed depressions. The largest of them lies beneath the lower part of Capps Glacier where the altitude of the glacier bed approaches sea level. Several smaller depressions exist further up the glacier. Another depression is present beneath the terminal area of Barrier Glacier which dams Chakachamna Lake (fig. 4). Most of the glacier bed under the terminal lobe of Barrier Glacier lies at an altitude lower than the surface of the lake (fig. 9 and plate 1 ) and at its lowest point, the glacier bed is $50-75 \mathrm{~m}$ lower than the bottom of adjacent Lake Chakachamna (lake bottom elevations from USGS 1:24,000 scale map: Chakachatna River and Chakachamna Lake, Alaska, 1960).

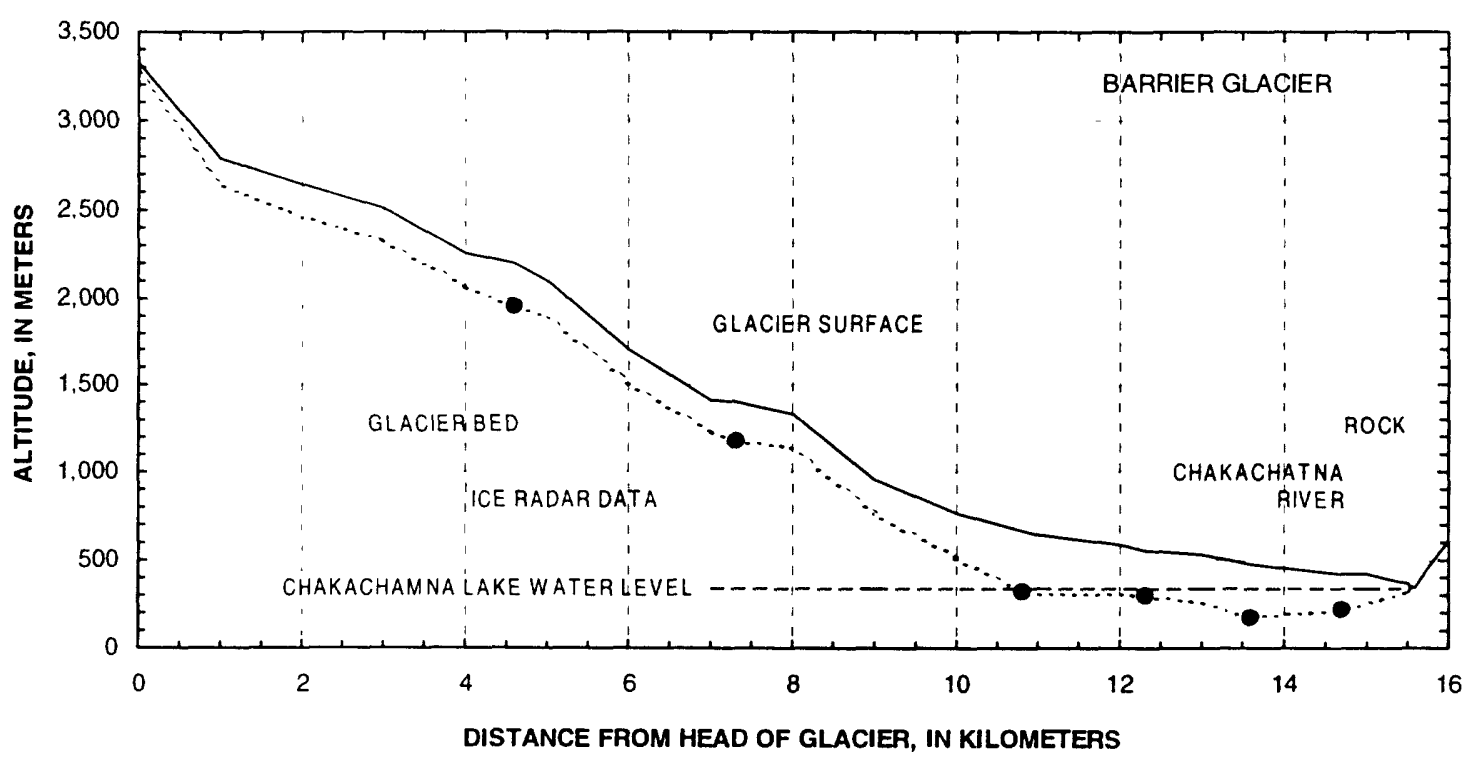

Figure 9. Longitudinal profiles of Barrier Glacier's surface and bed with approximately $2 \times$ vertical exaggeration. The profile is drawn to the southern terminus of the glacier were the glacier terminates at the Chakachatna River. Chakachamna Lake water level is from USGS 1:24,000 scale map: Chakachatna River and Chakachamna Lake, Alaska, 1960. The glacier bed reaches to about 170 meters below the lake level.

Because Chakachamna Lake's outlet channel, the Chakachatna River, is constricted by the leading edge of Barrier Glacier (Lamke, 1972), a change in the health of the glacier could affect the lake's stability. An ongoing balance exists between the glacier and the lake. While Barrier Glacier is constantly moving forward trying to further constrict the lake outlet, the Chakachatna River, in turn, erodes the glacier terminus. The glacier supplies rock to its terminus, which helps buffer the glacier from the erosive power of the river, while at the same time the glacier adds bed material to the river, which may help maintain its grade. In August 1971, the balance was broken during a period of exceptionally high rainfall when lateral erosion of the channel constriction formed by Barrier Glacier triggered an outburst flood from Chakachamna Lake (Lamke, 1972). The lake level dropped about $4.3 \mathrm{~m}$ during the outburst and the discharge reached an estimated peak of 
$13,300 \mathrm{~m}^{3} / \mathrm{s}$ (Lamke, 1972) which is the fifth largest known glacier outburst in the world in historic times (Mayo, 1988).

The Chakachatna River level declines about 5-8 $\mathrm{m}$ in passing the glacier (USGS 1:24,000 scale map: Chakachatna River and Chakachamna Lake, Alaska, 1960). This decline suggests that Barrier Glacier's constriction of the lake outlet channel may be supporting the lake at an altitude as much as 5-8 $\mathrm{m}$ higher than it would be without the glacier's damming effect. If Barrier Glacier were to retreat significantly, a slight lowering of the lake and a possible extension of Chakachamna Lake into the area now occupied by the glacier might result, unless the surficial deposits currently separating the lake from the glacier are sufficient to hold back the lake after the glacier's support is withdrawn. If Barrier Glacier were to advance significantly, outbursts would be more common (Post and Mayo, 1972).

Volcanic activity on Mount Spurr could result in either an advance or a retreat of Barrier Glacier. A significant ashfall over the ablation area could reduce or eliminate glacier ablation, resulting in a strongly positive glacier balance that would be likely to lead to its advance. Alternatively, an eruption could eliminate part of the glacier's accumulation zone or erode the glacier's surface, resulting in a thinner glacier. Either of these events would likely lead to a reduction in the speed of the glacier and a retreat of its terminus.

The summit cone of Mount Spurr appears on topographic maps to be a simple cone, but stereo vertical photography shows that it has a small crater, about 200-300 $\mathrm{m}$ in diameter, that is mostly ice filled and partly breached on its east side. The inside of the north wall was mostly free of snow in 1957 photographs (USGS aerial mapping photography) and one can see down into the crater although not all the way to the bottom. Photographs from 1978 (NASA high altitude false color infra-red) show less bare ground and indicate that the crater may have filled with snow. This crater is a site for the potential impoundment of water from melting snow and ice which might be released as a jökulhlaup (outburst flood) that would most likely travel down the Kidazqeni Glacier and into the Chakachatna River.

Another site for the potential impoundment of water, which could also be released as a jökulhlaup, is the 2-3-km-wide basin to the northwest of the summit of Mount Spurr. The snow and ice in this basin flows to the northeast and down the South branch (informal name) of the Capps Glacier (fig. 10), so possible flooding would affect the Chichantna River.

Wescott and others (1986) measured ice depths at 18 sites in this basin using both a $5.5 \mathrm{MHz}$ monopulse ice-radar system and a method using the VLF signal from the U.S. Navy transmitter in Hawaii. The ice-radar measurements from this study indicate ice depths of less than $100 \mathrm{~m}$ up to a maximum of about $200 \mathrm{~m}$. Ice depths from the magnetotelluric methods were generally two to three times greater (maximum depth of $575 \mathrm{~m}$ ) than the depths determined by ice radar. The study concluded that the ice-radar reflections were coming from a major englacial ash layer well above the glacier bed.

At Site 32 (fig. 11), our ice-radar measurement of 370-m-deep ice in this basin is in agreement with the interpretation that the ice-radar measurements by Wescott and others (1986) were too shallow and may have recorded reflections off an englacial horizon. The ice-radar measurement is roughly 25 percent shallower than that indicated by the contours of Wescott and others (1986), but can be shown to agree with the data from Wescott and others (1986) by slightly modifying their contours (fig. 11). 


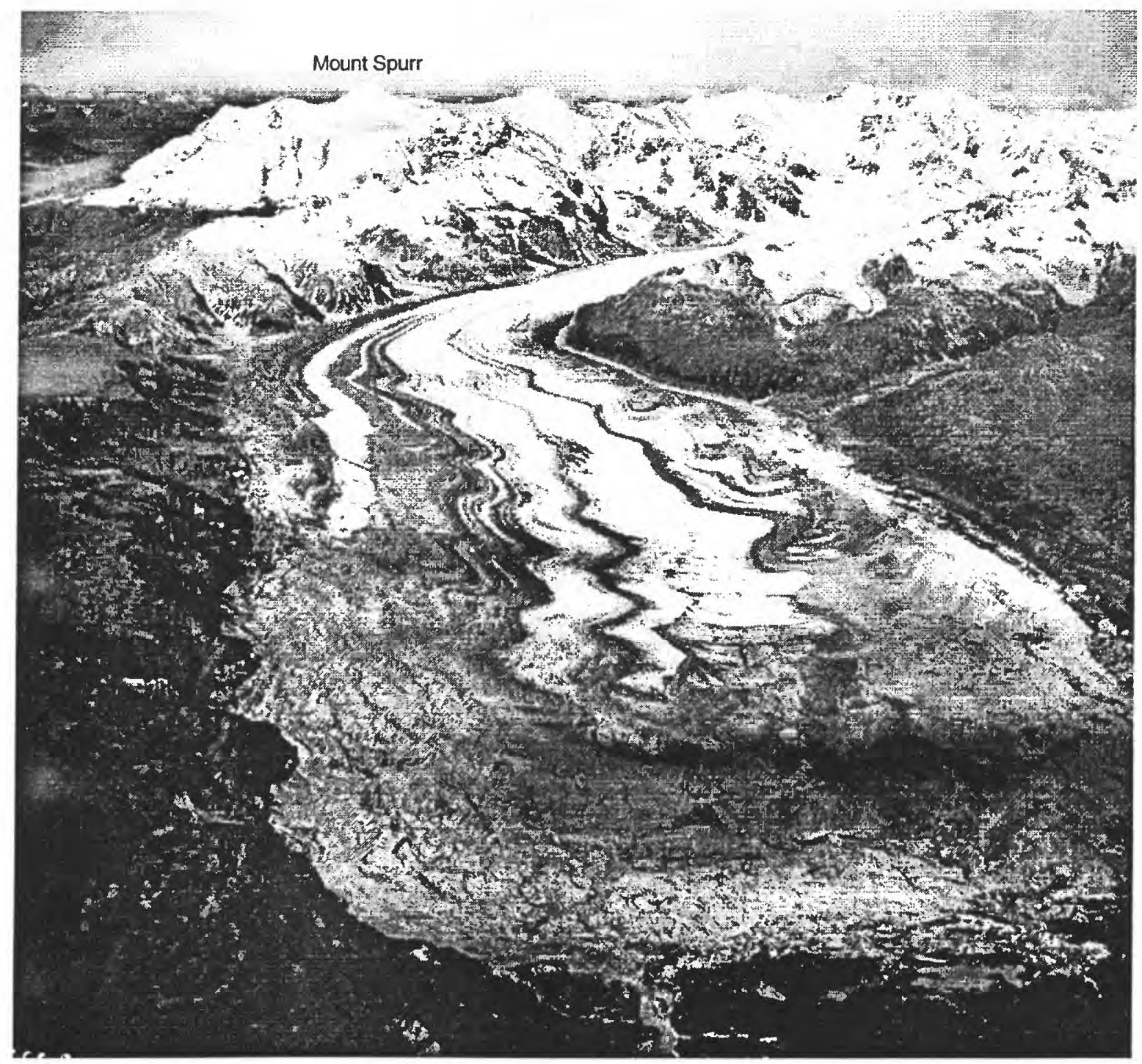

Figure 10. Mount Spurr Volcano seen from the east with Capps Glacier in the foreground on September 4, 1966. The folded moraines on the glacier surface indicate that Capps Glacier probably undergoes surges (Post, 1969). Capps Glacier was reported to be pulsing in August 1975 (Mayo, 1978). The summit crater, Mount Spurr, appears in the upper left of the photo along the skyline. (U.S. Geological Survey photograph by Austin Post, \#666-2.)

Basal contours of the magnetotelluric data show the basin gradually deepening to the northeast (fig. 11). However, as neither the data nor the contours extend to the break in slope of the ice surface, it is not known whether this subglacial basin is open or closed (fig. 12). If the basin is open, water can be impounded subglacially only if a depression forms in the glacier surface, and such a depression would be visible. If the basin is closed, water could be impounded without any visible change in the glacier surface. Björnsson (1975) describes subglacial conditions under which water 


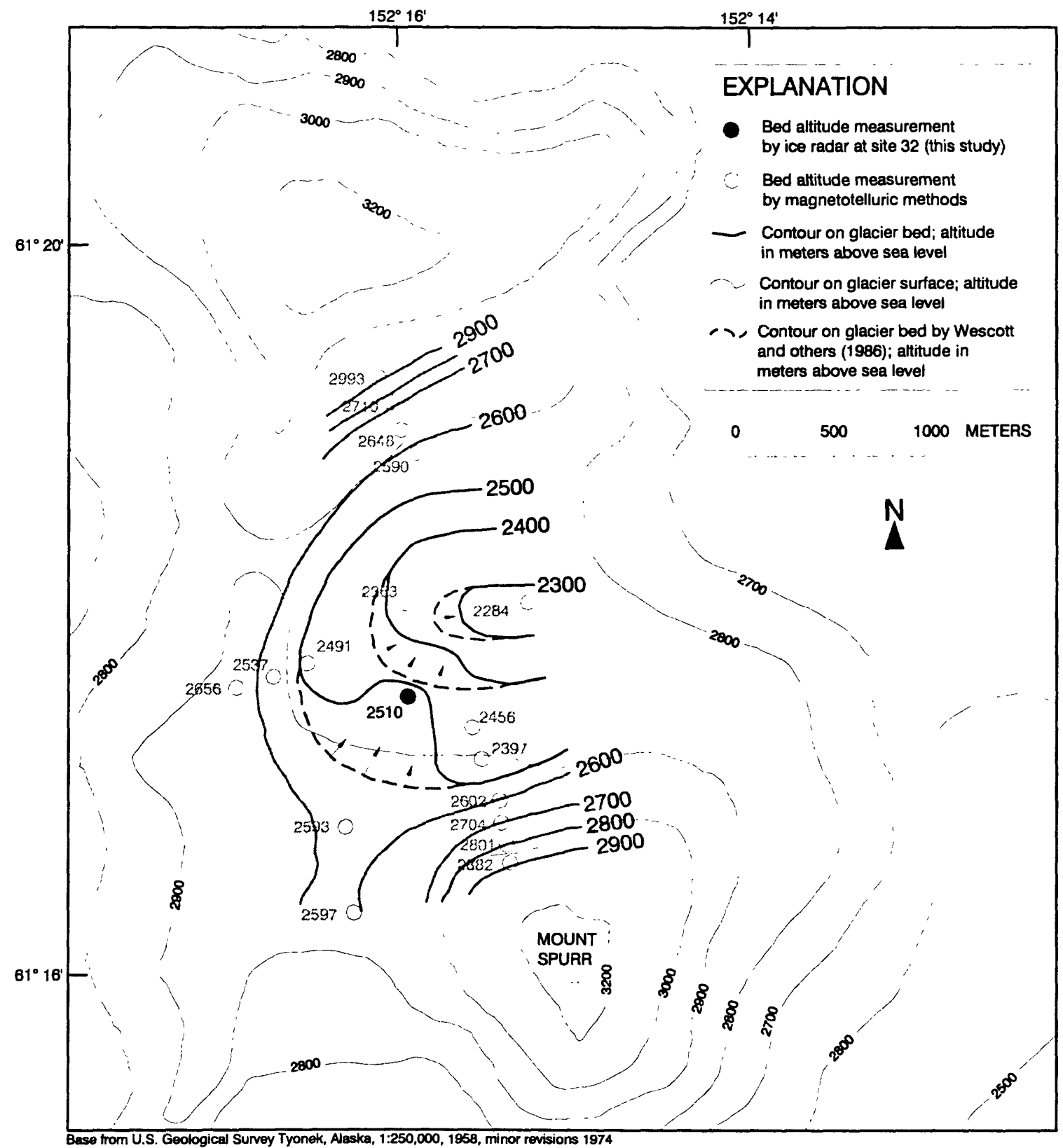

Figure 11. Glacier surface and bed topography of the summit region of Mount Spurr modified from Wescott and others (1986). Arrows show how contours by Wescott and others (1986) were revised to accommodate our ice-radar sounding without violating their magnetotelluric soundings.

reservoirs form. If the basin is open, the bed must remain below $2,284 \mathrm{~m}$ (the deepest point measured by Wescott and others, 1986) to the east of that point, and ice depths near the east edge of the basin (near question mark in fig. 12) would be 470,370 , and $220 \mathrm{~m}$ on glacier surface slopes of 16 , 22 , and 31 grad, respectively (fig. 12). However, this would result in estimated basal shear stress values greater than $500 \mathrm{kPa}$, which would be quite unlikely, thus suggesting that the basin may be 
closed to the northeast as is shown on plate 1. Whether this basin is open or closed, the overall snow and ice volumes would not be significantly different because the area affected is relatively small.

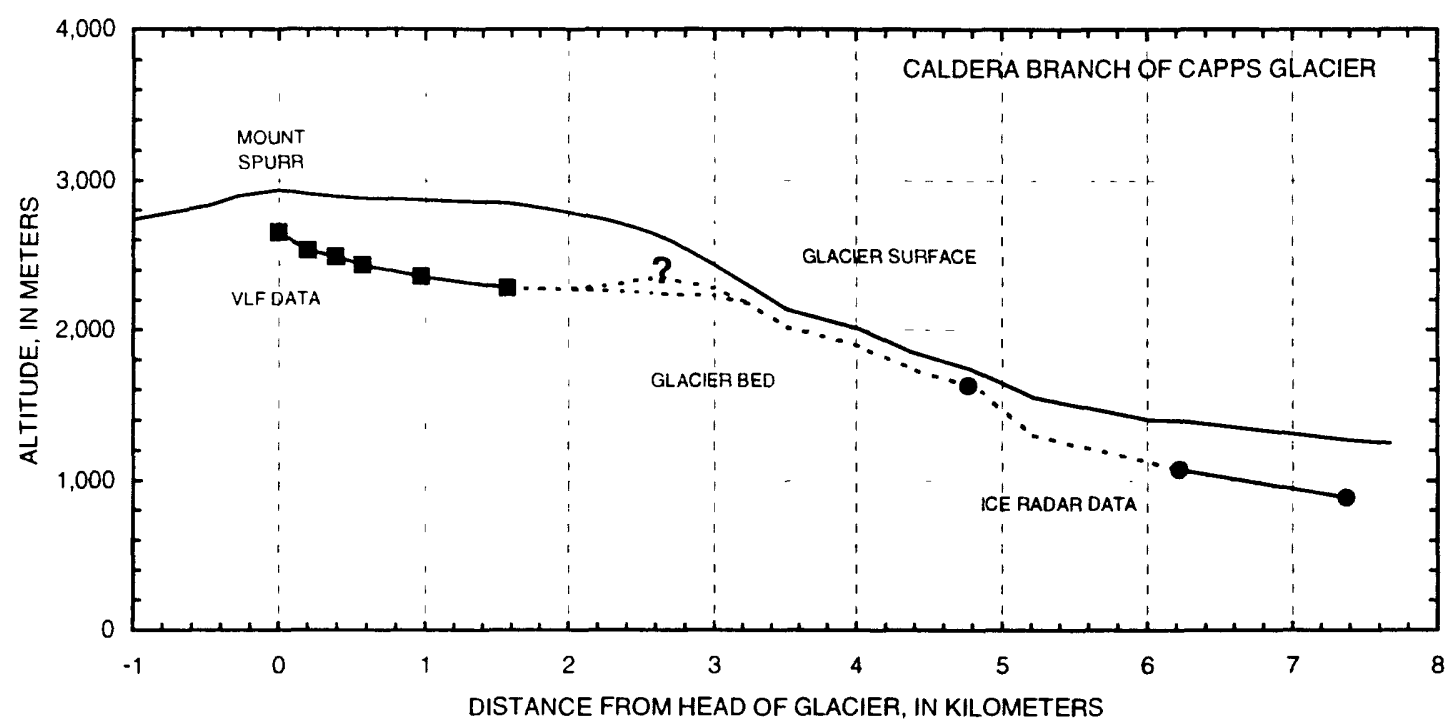

Figure 12. Longitudinal profiles of upper South branch of Capps Glacier's surface and bed. VLF magnetotelluric measurements from Wescott and others (1986).

\section{Use of Glacier Volumes at Mount Spurr to Improve Volume-Estimation Methods}

The areas and volumes of Mount Spurr glaciers can be used together with similar observations in the Cascade Range of Washington, Oregon, and California to arrive at a simple means of estimating glacier volumes. An ordinary least squares (linear) regression (fig. 13) of the log of glacier volume versus the log of glacier area (power fit of volume versus area) yields the following relation:

$$
\log \hat{V}=1.31 \log A-1.39
$$

or,

$$
\hat{V}=0.041 A^{1.31}
$$

where $\hat{V}$ is the estimated volume in cubic kilometers and $A$ is the area in square kilometers. The standard error of the estimate (of volume) from this relation is about \pm 35 percent. Worst case residuals are about 50 percent in error. Because this relation is itself based on the transformed $(\log )$ values of partially estimated variables, the regression statistics are not necessarily meaningful and estimates of the untransformed variables may be systematically biased high or low. Glacier volumes estimated from equation 5 are a first and very simple estimation of volume that is within the stated accuracy over a wide range of glacier sizes in diverse climatic regions. 


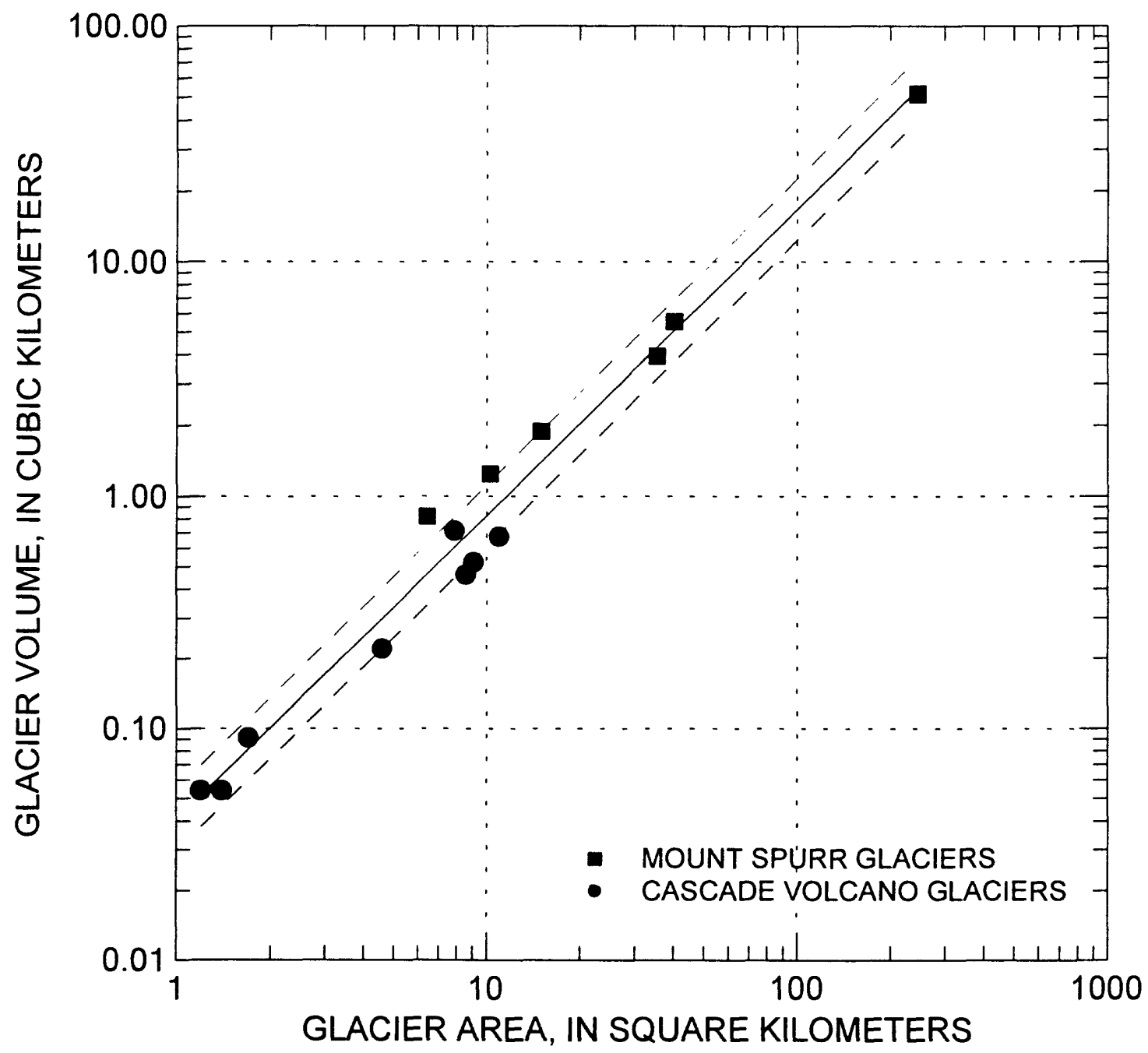

Figure 13. Log-log scatter plot of glacier volume versus glacier area for Mount Spurr glaciers (this report) and Cascade Range glaciers on volcanoes (Driedger and Kennard, 1986). Linear regression of all data is shown as a solid line and the standard error of the estimate from the regression is shown by the dashed lines.

\section{Glaciovolcanic Hazards and Comparison With Other Volcanoes}

There is a serious lack of information in the literature about the relation between the magnitude of hydrologic hazards on volcanoes and the quantity of snow and ice present on a volcano during an eruption. Nevertheless, it seems reasonable to assume that up to some limit of snow and ice, there should be a positive, though not necessarily linear, relation between the potential hazard magnitude and the area or volume of snow and ice immediately surrounding the volcano.

To date, Mount Spurr is the most heavily glaciated volcano in the United States on which the snow and ice distribution has been determined. The snow and ice distribution was measured on five 
volcanoes in the Cascade Range (Brugman and Meier, 1981; Driedger and Kennard, 1986a) and preliminary total values, which are likely to be revised, have been estimated for Mount Redoubt (table 13).

Table 13. Summary of snow and ice minimum seasonal area (September), maximum seasonal area (May), and volume above altitude of glacier termini. Seasonal variations were not measured or estimated for any of the Cascade Volcanoes except glacier thickness on Mount St. Helens, which varies seasonally by more than 10 percent of the glacier depth (Brugman and Meier, 1980). It is expected that the areas listed for the other Cascade Volcanoes may increase seasonally by $30-200$ percent and volumes by $10-50$ percent

|km . square kilometers: $\mathrm{km}^{\prime}$. cubic kilometers]

\begin{tabular}{|c|c|c|c|}
\hline \multirow[b]{2}{*}{ Glacier/Drainage Name } & \multicolumn{2}{|c|}{ Snow and Ice } & \multirow[b]{2}{*}{$\begin{array}{c}\text { Volume } \\
\left(\mathrm{km}^{3}\right)\end{array}$} \\
\hline & $\begin{array}{c}\text { Seasonal } \\
\text { Minimum } \\
\text { Area } \\
\left(\mathrm{km}^{2}\right)\end{array}$ & $\begin{array}{c}\text { Seasonal } \\
\text { Maximum } \\
\text { Area } \\
\left(\mathrm{km}^{2}\right)\end{array}$ & \\
\hline \multicolumn{4}{|l|}{ Chakachatna River drainage: } \\
\hline Barrier Gl. & 40.2 & 52.2 & 5.6 \\
\hline Crater gl. & 10.4 & 14.0 & 1.3 \\
\hline West Kidazqeni Gl. & 6.5 & 8.2 & 0.8 \\
\hline East Kidazqeni Gl. & 15.1 & 20.3 & 1.9 \\
\hline Painted gl. & 35.5 & 59.2 & 3.9 \\
\hline Total & 107.7 & 153.9 & 13.5 \\
\hline \multicolumn{4}{|l|}{ Chichantna River drainage: } \\
\hline Capps, Main branch & 215.3 & 268.0 & 47.5 \\
\hline Capps, South branch & 32.8 & 36.5 & 5.7 \\
\hline Total & 248.1 & 304.5 & 53.2 \\
\hline Mount Spurr Total & 355.8 & 458.4 & 66.7 \\
\hline \multicolumn{4}{|l|}{ Cascade Volcanoes: } \\
\hline North Fork Toutle River Drainage & 2.39 & -- & 0.097 \\
\hline Total & 5.02 & -- & 0.179 \\
\hline \multicolumn{4}{|l|}{ Mt. Rainier ${ }^{2}$} \\
\hline White River Drainage Area & 26.64 & - & 1.337 \\
\hline Total & 92.09 & - & 4.424 \\
\hline Mount Redoubt Total (preliminary) & 96.9 & - & 4.09 \\
\hline
\end{tabular}

1 Brugman and Meier, 1980. (The North Fork Toutle River Drainage values are the sum of Brugman and Meier's values for Forsyth, Wishbone, Loowit, and Leshi glaciers)

2 Driedger and Kennard, 1984, 1986 
Mount Spurr has approximately 350 times more snow and ice than did Mount St. Helens before its May 1980 eruption, and 15 times more than Mount Rainier, the most glacierized of the volcanoes in the Cascade Range. The less glacierized of the two drainages on Mount Spurr, the Chakachatna River drainage ( $13.5 \mathrm{~km}^{3}$ of snow and ice) has roughly 140 times more snow and ice than the North Fork Toutle River drainage on Mount St. Helens had before its eruption, and 10 times more than the most heavily glacierized single drainage basin on any of the volcanoes in the Cascade Range, the White River drainage on Mount Rainier ( $1.34 \mathrm{~km}^{3}$ of snow and ice).

The preliminary rough estimates of snow and ice on Mount Redoubt indicate that, before the eruptive sequence which began on December 14, 1989, it had about one-third as much snow and ice as Mount Spurr, but considerably more than that on Cascade Range volcanoes.

On the basis of relative size, it is expected that glaciovolcanic hazards at Mount Spurr (such as floods, mudflows, and debris flows) could be significantly greater than at Cascade volcanoes. The actual glaciovolcanic hazards produced during an eruption depend as much on the nature and magnitude of the eruption as on the quantity of snow and ice. This is well illustrated by a comparison of the snow and ice perturbation during the May 1980 eruption of Mount St. Helens (Brugman and Meier, 1981) with that during the 1989-90 eruptive sequence of Mount Redoubt (Alaska Volcano Observatory Staff, 1990). Despite the great difference in the quantity of snow and ice present on these two volcanoes before these eruptions (table 13), each lost about the same quantity of snow and ice (about $0.1 \mathrm{~km}^{3}$ ) during their eruptions.

\section{SUMMARY AND CONCLUSIONS}

Ice thickness was measured at 64 sites on Mount Spurr volcano with a portable $1.7 \mathrm{MHz}$ monopulse ice-radar system. At four additional sites, the ice thickness was measured at vertical ice cliffs using a helicopter altimeter. Contour maps of ice depth and subglacial topography from the ice-thickness measurements show that the total area of permanent snow and ice on Mount Spurr is $360 \mathrm{~km}^{2}$ with an average ice thickness of $190 \pm 50 \mathrm{~m}$, for a total snow and ice volume of $67 \pm 17 \mathrm{~km}^{3}$ $\left(60 \mathrm{~km}^{3}\right.$ water equivalent). Most non-glacier areas are covered seasonally by snow with an average water equivalent of about $1 \mathrm{~m}$ at the end of winter. This amounts to an additional $100 \mathrm{~km}^{2}$ or a 30 percent increase in the snow- and ice-covered area, but only a 1 percent increase in ice volume.

All of the snow and ice measured on Mount Spurr lies in the Chakachatna River basin or the Chichantna River basin. Roughly 66 percent of the area and 80 percent of the volume of snow and ice lie in the Chichantna River basin, a sub-drainage of the Beluga River.

Unusually high basal shear stresses were estimated for glaciers on Mount Spurr. At 20 percent of the sites, basal shear stresses between 200 and $350 \mathrm{kPa}$ were estimated. The normal range of basal shear stresses referred to in the literature is $50-150 \mathrm{kPa}$. We conclude that the expanded range of basal shear stresses found at Mount Spurr is normal and that there simply have not been many determinations of basal shear stress on steep glaciers due to the difficulty of working on them.

Mount Spurr has approximately 350 times more snow and ice than did Mount St. Helens before its May 1980 eruption, and 15 times more than Mount Rainier, the most glacierized of the volcanoes in the Cascade Range. On the basis of comparison of the relative quantities of snow and ice, the glaciovolcanic hazards at Mount Spurr (such as floods, mudflows, and debris flows) are 
expected to be significantly greater than at Cascade volcanoes. However, the actual glaciovolcanic hazards produced during any particular eruption are expected to be extremely variable and highly dependent on the nature and magnitude of the eruption as well as on the quantity of snow and ice.

\section{REFERENCES CITED}

Alaska Volcano Observatory Staff, 1990, The 1989-1990 eruption of Redoubt Volcano: Eos Transactions, American Geophysical Union, v. 71, no. 7, p. 265, 272-273, 275.

Bechtel Civil \& Minerals Inc., 1983, Chakachamna hydroelectric project interim feasibility assessment report, Volume I, Sections 1-10: for Alaska Power Authority.

Björnsson, Helgi, 1975, Subglacial water reservoirs, jökulhlaups and volcanic eruptions: Jökul, v. 25, p. 1-12.

Brugman, M.M., and Meier, M.F., 1981, Response of glaciers to the eruptions of Mount St. Helens, in Lipman, P. W., and Mullineaux, D. R., eds., The 1980 eruptions of Mount St. Helens, Washington: U.S. Geological Survey Professional Paper 1250, p. 743-756.

Departments of the Army and the Air Force, 1941, TM 5-241- to 16-1-233, The universal grid systems (Universal Transverse Mercator and Universal Polar Stereographic): Washington, U.S. Government Printing Office, 324 p. (Specifically page 219 and appendixes IV and V.)

Driedger, C.L., and Kennard, P.M., 1984, Ice volumes on Cascade Volcanoes: Mount Rainier, Mount Hood, Three Sisters, and Mount Shasta: U.S. Geological Survey Open-File Report 84-581, 55 p.

Driedger, C.L., and Kennard, P.M., 1986a, Ice volumes on Cascade Volcanoes: Mount Rainier, Mount Hood, Three Sisters, and Mount Shasta: U.S. Geological Survey Professional Paper 1365, 28 p.

Driedger, C.L., and Kennard, P.M., 1986b, Glacier volume estimation on Cascade Volcanoes: An analysis and comparison with other methods: Annals of Glaciology, v. 8, p. 59-64.

Jackson, B.L., 1961, Potential waterpower of Lake Chakachamna, Alaska: U.S. Geological Survey Open-File Report, $20 \mathrm{p}$.

Jacobel, Robert, and Raymond, Charles, 1984, Radio echo-sounding studies of englacial water movement in Variegated Glacier, Alaska: Journal of Glaciology, v. 30, no. 104, p. 22-29.

Johnson, Arthur, 1950, Report on reconnaissance of Lake Chakachamna, Alaska: U.S. Geological Survey Open-File Report, 8 p., 4 plates.

Juhle, Werner, and Coulter, Henry, 1955, The Mt. Spurr eruption, July 9, 1953: Transactions, American Geophysical Union, v. 36, no. 2, p. 199-202.

Keith, T.E.C., ed., 1995, The 1992 eruptions of Crater Peak vent, Mount Spurr Volcano, Alaska: U.S. Geological Survey Bulletin 2139, $220 \mathrm{p}$.

Kennard, P.M., 1983, Volumes of glaciers on Cascade volcanoes: Seattle, Washington, University of Washington, M.S. thesis, $151 \mathrm{p}$.

Lamke, R.D., 1972, Floods of the summer of 1971 in south-central Alaska: U.S. Geological Survey Open-File Report, $88 \mathrm{p}$.

Major, J.J., and Newhall, C.G., 1989, Snow and ice perturbation during historical volcanic eruptions and the formation of lahars and floods, a global review: Bulletin of Volcanology, v. 52, p.1-27.

March, R.S., Mayo, L.R., and Trabant, D.C., 1986, Geodetic survey stations near Mount Spurr Volcano, Alaska: U.S. Geological Survey Open-File Report 86-137, 14 p.

Mayo, L.R., 1986, Annual runoff rate from glaciers in Alaska, a model using the altitude of glacier mass balance equilibrium, in Kane, D.L., ed., Proceedings of the Symposium Cold Regions Hydrology: American Water Resources Association, p. 509-517. 
Mayo, L.R., 1988, Advance of Hubbard Glacier and closure of Russell Fiord, Alaska-Environmental effects and hazards in the Yakutat area, in Galloway, J.P. and Hamilton, T.D., eds., Geological studies in Alaska by the U.S. Geological Survey during 1987: U.S. Geological Survey Circular 1016, p. 4-16.

Mayo, L.R., and Trabant, D.C., 1982, Geodetic trisection, altitude, and ice-radar surveying techniques used at Knik Glacier, Alaska, and summary of 1979, 1980, and 1981 data: U.S. Geological Survey Open-File Report 82-685, $26 \mathrm{p}$.

Mayo, L.R., Trabant, D.C., March, Rod, and Haeberli, Wilfried, 1979, Columbia Glacier stake location, mass balance, glacier surface altitude, and ice radar data, 1978 measurement year: U.S. Geological Survey Open-File Report 79-1168, $72 \mathrm{p}$.

Meyer, D.F., and Trabant, D.C., 1995, Lahars from the 1992 eruptions of Crater Peak, Mount Spurr Volcano, Alaska, in Keith, T.E.C., ed., The 1992 eruptions of Crater Peak vent, Mount Spurr Volcano, Alaska: U.S. Geological Survey Bulletin 2139, p. 183-198.

Nye, C.J., and Turner, D.L., 1990, Petrology, geochemistry, and age of the Spurr volcanic complex, eastern Aleutian arc: Bulletin of Volcanology, v. 52, p. 205-226.

Nye, J.F., 1951, The flow of glaciers and ice-sheets as a problem in plasticity: Proceedings of the Royal Society of London, A, v. 207, p. 554-572.

Paterson, W.S.B., 1981, The physics of glaciers: New York, Pergamon Press, 380 p.

Post, Austin and Mayo, L.R., 1972, Glacier-dammed lakes and outburst floods in Alaska: U.S. Geological Survey Hydrologic Investigations Atlas HA-455, 10 p., 3 plates

Riehle, J.R., 1985, A reconnaissance of the major Holocene tephra deposits in the upper Cook Inlet region, Alaska: Journal of Volcanology and Geothermal Research, v. 26, p. 37-74.

Schmitt, N.C., 1984, Diamond Chulitna coal project could become operational in '88: Alaska Oil and Gas News, September, p. 18.

Siebert, L., 1984, Large volcanic debris avalanches: characteristics of source areas, deposits, and associated eruptions: Journal of Volcanology and Geothermal Research v. 22, p. 163-197.

Trabant, D.C., and Mayo, L.R., 1979, Knik Glacier, Alaska-May 1979 monument and glacier survey: U.S. Geological Survey Open-File Report 80-48, 20 p.

U.S. Soil Conservation Service, 1982-85, Snow surveys and water supply outlook for Alaska: Monthly reports.

Waddington, E.D., 1986, Wave ogives: Journal of Glaciology, v. 32, no. 112, p. 325-334.

Waitt, R.B., 1995, Hybrid wet flows formed by hot pyroclasts interacting with snow during the 1992 eruptions of Crater Peak, Mount Spurr Volcano, Alaska, in Keith, T.E.C., ed., The 1992 eruptions of Crater Peak vent, Mount Spurr Volcano, Alaska: U.S. Geological Survey Bulletin 2139, p. 107-118.

Warren, S.G., 1984, Optical constants of ice from the ultraviolet to the microwave: Applied Optics, v. 23, no. 8, p. 1206-1225.

Watts, R.D., and England, A.W., 1976, Radio echo sounding of temperate glaciers: ice properties and sounder design criteria: Journal of Glaciology, v. 17, no. 75, p. 39-48.

Watts, R.D., and Wright D.L., 1981, Systems for measuring thickness of temperate and polar ice from the ground or from the air: Journal of Glaciology, v. 27, no. 97, p. 459-469.

Wescott, E.M., Turner, D.L., Nye, C.J., Motyka, R.J., and Moore, P., 1988, Exploration for geothermal energy resources at Mt. Spurr, Alaska: Geothermal Resources Council, v. 12, p. 203-210.

Wescott, E.M., Witte, W., Moore, P., and Echelmeyer, K., 1986, Ice thickness measurements in the basin surrounding the summit of Mt. Spurr, Alaska, in Turner, D.L., and Wescott, E.M., eds., Geothermal energy resource investigations at Mt. Spurr, Alaska: University of Alaska Geophysical Institute Report UAG R-308, p. 3-1 to 3-13. 


\section{APPENDIX. COORDINATE SYSTEMS}

A local sea-level-scale coordinate system, based on the Universal Transverse Mercator (UTM) grid and similar to that used by the authors elsewhere (Mayo and others, 1979; Trabant and Mayo, 1979), was adopted for use at Mount Spurr. The origin of the Mount Spurr local system is at UTM coordinates $520,000 \mathrm{~m}$ Easting, 6,770,000 $\mathrm{m}$ Northing in Zone 5. The conversion between the UTM system and the local sea-level system is defined by:

$$
\begin{aligned}
\text { UTM Easting } & =k X_{o}+520,000 \\
\text { UTM Northing } & =k Y_{o}+6,770,000
\end{aligned}
$$

in which $X_{o}$ and $\mathrm{Y}_{o}$ are local sea-level coordinates in $\mathrm{m}$ and $k$ is the mean horizontal scale factor between the UTM plane and sea level. The scale factor, $k$, at a point is a variable defined by:

$$
k=\frac{0.996}{\sin \left(100+\frac{500,000-E}{10^{5}}\right)}
$$

in which $E$ is the UTM Easting of the point and the trigonometric function is evaluated in grad.

The mean scale factor used in equations A-1 and A-2 to convert between the local sea-level system coordinates and UTM coordinates is the mean value of the nonlinear distribution of scale factors between the local sea-level system origin and an observation point. Here it is obtained using Simpson's $1 / 3$ rule. $E$ is approximated by the sum of the UTM Easting of the local system origin $(520,000 \mathrm{~m})$ and $X_{o}$.

$$
k=\frac{0.9996}{6}\left(\frac{1}{\sin \left(100+\frac{500,000-(520,000)}{100,000}\right)}+\frac{4}{\sin \left(100+\frac{500,000-(520,000)-\frac{1}{2} x_{o}}{100,000}\right)}+\frac{1}{\sin \left(100+\frac{500,000-(520,000)-x_{o}}{100,000}\right)}\right)
$$

Equation A-4 is accurate within about 0.1 parts per million of equations from Departments of the Army and the Air Force (1941) and hence yields results accurate at the centimeter level. Altitudes are the same in both the local coordinate system and the UTM system. 